\title{
Meddies in the Mercator North Atlantic and Mediterranean Sea eddy-resolving model
}

\author{
Yann Drillet, ${ }^{1}$ Romain Bourdallé-Badie, ${ }^{1}$ Laure Siefridt, ${ }^{1}$ and Christian Le Provost ${ }^{2}$ \\ GIP Mercator Océan, Ramonville St. Agne, France \\ Received 17 October 2003; revised 29 September 2004; accepted 26 January 2005; published 17 March 2005.
}

[1] The new generation of high-resolution ocean models offers a new way to investigate the characteristics and the evolution of the ocean mesoscale. An analysis of the simulated Mediterranean eddies, the so-called "meddies," is presented. The model used in this study is the Mercator North Atlantic $\left[9^{\circ} \mathrm{N}, 70^{\circ} \mathrm{N}\right]$ and Mediterranean Sea Prototype (PAM), a high-resolution configuration (3.5-8 km horizontal grid) based on the OPA ocean general circulation model. The meddies are coherent structures of warm and salt Mediterranean Water (MW) advected in the northeast Atlantic. A 5 year experiment performed with PAM reproduced the main observed characteristics of the meddies: thermohaline properties $\left(11.8^{\circ} \mathrm{C}, 36 \mathrm{psu}\right.$ ), sizes (radius between 25 and $110 \mathrm{~km}$ ), thickness (between 500 and $1000 \mathrm{~m}$ ), westward advection velocities $\left(1.4 \mathrm{~cm} . \mathrm{s}^{-1}\right)$, angular velocities (a period of 20 days), a good estimate of the number of meddies in the northeast Atlantic ( 22), and their realistic geographical distribution $(80 \%$ south of $40^{\circ} \mathrm{N}$ ). Moreover, and in agreement with a previous study based on an observation cruise, these modeled meddies represent half of the westward salinity transport of MW.

Citation: Drillet, Y., R. Bourdallé-Badie, L. Siefridt, and C. Le Provost (2005), Meddies in the Mercator North Atlantic and Mediterranean Sea eddy-resolving model, J. Geophys. Res., 110, C03016, doi:10.1029/2003JC002170.

\section{Introduction}

[2] In the context of the MERCATOR operational oceanography project (http://www.mercator-ocean.fr), we have studied the representation by the North Atlantic and Mediterranean Sea Prototype (PAM) of the meddies. These oceanic eddies are defined as salty lenses of Mediterranean Water (MW) created in the Atlantic by the interaction of the MW vein and the topography. The ability of such a model to reproduce these kinds of structures will be really useful to complete studies based on observations. Statistical studies, about the meddy geographical distribution for example, based on model simulation now appear close to the reality when such studies are always difficult to carry out with a too few measurements.

[3] The meddies have been studied for more than 20 years; one of the first references to these structures was made by McDowell and Rossby [1978]. Since then, many hydrographic cruises in the northeast Atlantic have revealed the hydrographic properties and velocity structures of the meddies have been described [Armi and Zenk, 1984; Paillet et al., 2002; Pingree and Le Cann, 1993; Richardson et al., 1991; Tychensky and Carton, 1998; Zenk et al., 1992]. Many theoretical and numerical studies have been done to

\footnotetext{
${ }^{1}$ Also at Centre Europeen de Recherche et de Formation Avancée en Calcul Scientifique, Toulouse, France.

${ }^{2}$ Also at Laboratoire d'Etudes en Géophysique et Océanographie Spatiales, Toulouse, France.

Copyright 2005 by the American Geophysical Union. 0148-0227/05/2003JC002170
}

describe the formation, evolution and propagation of coherent vortices in the ocean and the interaction of these structures with the bathymetry [Aiki and Yamagata, 2004; Beckmann and Käse, 1989; Colin de Verdière, 1992; Dewar, 2002; Jungclaus, 1999; Killworth, 1986; Morel, 1995; Morel and McWilliams, 1997; Pichevin and Nof, 1996]. PAM allows a resolution of the order of $6 \mathrm{~km}$ in the meddy formation area around St. Vincent Cape, quite similar to some previous studies based on quasi-geostrophic models [Beckmann and Käse, 1989; Morel and McWilliams, 1997] or used to simulate a limited area [Jungclaus, 1999]. The large geographic domain in PAM configuration allows us to track the meddies in the entire North Atlantic domain.

[4] After a description of the model configuration in section 2 and of the Mediterranean Water outflow in section 3 , the meddy properties in a PAM 5 year simulation will be analyzed in section 4 . The interesting points are the thermohaline structure and the dynamic of the meddies, the events of splitting and coalescence, the number and lifetime of the meddies and the salinity anomaly they advect.

\section{Model Configuration}

[5] The PAM model provides a description of the North Atlantic (from $9^{\circ}$ to $70^{\circ} \mathrm{N}$ ) and Mediterranean basins [Siefridt et al., 2002] (available at http://www.mercatorocean.fr/html/lettre/lettre_5/page_1.html), with a very high horizontal resolution $(5-7 \mathrm{~km})$. The vertical resolution is based on 43 levels with layer thickness ranging from $6 \mathrm{~m}$ at the surface to $200 \mathrm{~m}$ at the bottom of the Mediterranean Sea, and $300 \mathrm{~m}$ for the Atlantic. The bathymetry is processed 


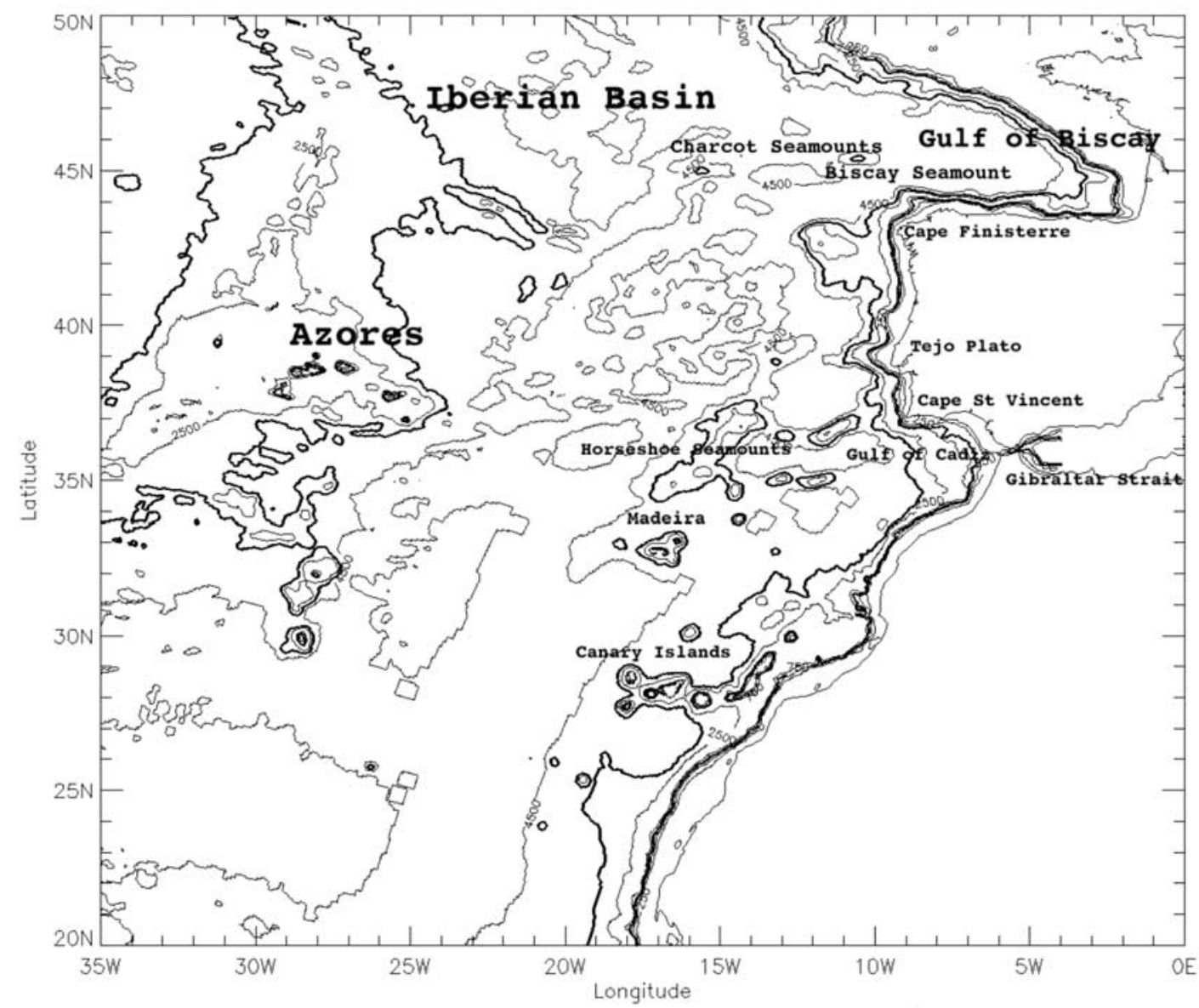

Figure 1. Smith and Sandwell [1994] bathymetry interpolated on the model grid in the meddies formation and displacement area. The bathymetry isocontours represented are $250 \mathrm{~m}, 500 \mathrm{~m}, 750 \mathrm{~m}$, $1000 \mathrm{~m}, 2500 \mathrm{~m}, 3500 \mathrm{~m}, 4500 \mathrm{~m}$, and $5500 \mathrm{~m}$, with a bold line for the $750 \mathrm{~m}$ and $3500 \mathrm{~m}$ isocontours.

from the Smith and Sandwell [1994] database (Figure 1). PAM uses version 8.1 [Madec et al., 1998] of the OPA numerical model, with vertical $z$ coordinates, including a rigid lid assumption at the surface, a diagnostic ice condition and a turbulent kinetic energy mixing parameterization (1.5 closure scheme). The viscosity and diffusivity operators are bilaplacian, with respectively a coefficient of $-9.10^{9}$ and $-3.10^{9} \mathrm{~m}^{2} \mathrm{~s}^{2}$ on the largest meshes; they decrease with the size of the mesh proportionally to $\Delta x^{3}$. The surface forcing function uses daily stress of wind, evaporation, precipitation, net heat and solar fluxes provided by the European Center for Medium-range Weather Forecasts (ECMWF) analyses over the 1998-2002 period. The PAM modeling project benefited from the CLIPPER research project [Treguier et al., 2001] for high-resolution modeling of the Atlantic Ocean. The main physical parameterizations in the PAM configuration are those in the CLIPPER configurations. The main improvements between CLIPPER and PAM are increased horizontal resolution and the addition of the Mediterranean Sea.

[6] The representation of the bathymetry by steps in the $z$ coordinate model is problematic for the simulation of the dense water sinking downstream of the Gibraltar Strait. Even with a high horizontal resolution (between 5 and
$10 \mathrm{~km}$ ) all these $z$ coordinate models have one of the following problems: intensity of the flow through the Gibraltar Strait; Mediterranean Water tongue depth; or thermohaline properties of this water mass. For example, Smith et al. [2000] simulate a warmer $\left(+2{ }^{\circ} \mathrm{C}\right)$ and saltier $(+0.4 \mathrm{psu})$ Mediterranean water tongue compared with the Reynaud climatology and the bathymetry in the PAM model prevents the dense water at $800 \mathrm{~m}$ where it is mixed with surrounding water instead of rapidly sinking down to $1000-1200 \mathrm{~m}$.

[7] In order to solve this numerical problem, a small relaxation, toward climatological temperature and salinity, three-dimensional (3-D) area in the Gulf of Cadiz was introduced in PAM [Drillet et al., 2002]. Such a solution has been adopted by M. E. Maltrud (personal communication, 2003) in a $1 / 10^{\circ}$ global ocean circulation model. In our case the relaxation area is centered at $8^{\circ} \mathrm{W}, 35^{\circ} \mathrm{N}$ with a $4^{\circ}$ radius. At the center the relaxation time is 50 days. This time is increased up to infinity $4^{\circ}$ away from the center. The relaxation is not constant over the vertical; it is only applied below $500 \mathrm{~m}$ and it is increased linearly between 500 to $1000 \mathrm{~m}$, where the relaxation time is 50 days at $8^{\circ} \mathrm{W}, 35^{\circ} \mathrm{N}$. Between $1000 \mathrm{~m}$ and the bottom of the ocean the coefficient value is unchanged. 

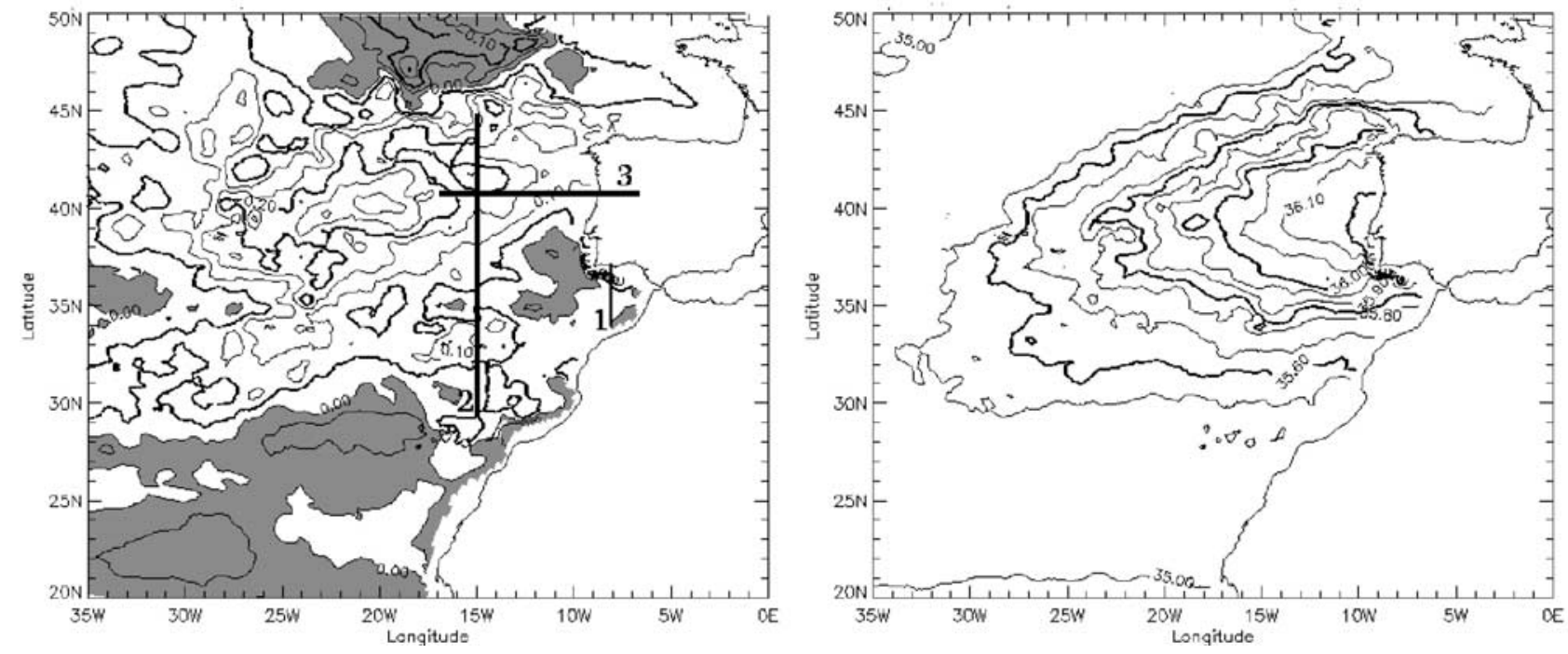

Figure 2. Salinity (psu) at $870 \mathrm{~m}$ depth. (left) Three year mean of simulation minus Reynaud climatology; the contour intervals are $0.05 \mathrm{psu}$. The areas where the climatology is saltier than the model are shaded. Vertical sections 1, 2, and 3 are plotted in Figures 3, 4, and 5. (right) Three year mean of simulation; the contour intervals in psu are $[35,35.5,35.6,35.7,35.8,35.85,35.9,35.95,36,36.05,36.1$, $36.15,36.2,36.3,36.4,36.5]$.

[8] In this configuration, the relaxation area is restricted to the Gulf of Cadiz where the MW current is strong and stable. At the St. Vincent Cape the relaxation time is 150 days at $750 \mathrm{~m}$ and 75 days under $1000 \mathrm{~m}$, and at Tejo Plato the model evolves freely. The small relaxation along these two capes does not inhibit the destabilization of the MW current which create meanders and eddies.

[9] The computational cost of this model allows us to perform only short simulations. One year of simulation needs 200 CPU hours on the Fujitsu VPP5000, 30 Go of memory and generates 100 Go of output fields. Consequently, the simulation analyzed in this paper simulates only the period 1998 to 2002 after a short 16 month spin-up period.
[10] The experiment (PAM21) analyzed in this study is initialized in September by the Reynaud climatology in the Atlantic [Reynaud et al., 1998] and by the MEDATLAS climatology in the Mediterranean Sea [Mediterranean Data Archeaology and Rescue, 2002]. The first 16 months of the simulation have been forced by the daily temporal mean of the 6 hour ECMWF forecast for the period between March 1998 and February 2000. Following this "spin-up," the interannual experiment simulates the period from March 1998 to August 2002. A short simulation is long enough to study the meddy formation and their displacement in the northeast Atlantic. After 2 years of simulations, the number of meddies is at equilibrium (see section 4.6.1), several meddies have reached the Mid-Atlantic Ridge. Neverthe-
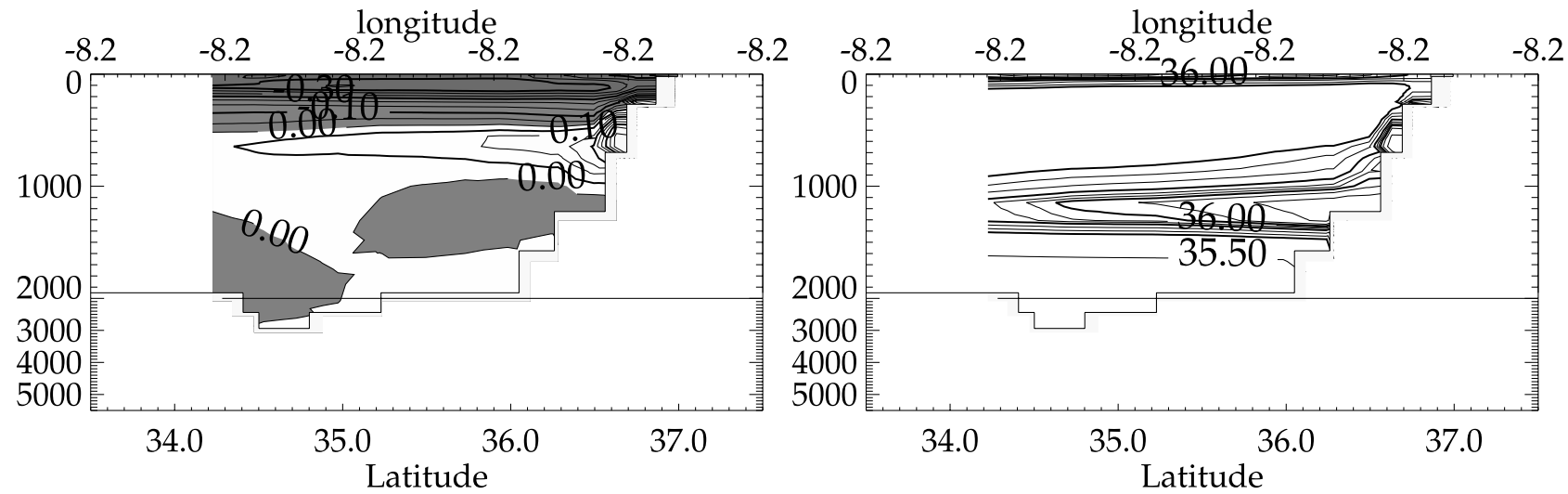

Figure 3. Salinity section (branch 1 (see Figure 2 )) in the Gulf of Cadiz $\left(8.2^{\circ} \mathrm{W}\right.$ ). (left) Three year mean of simulation minus climatology; the contour intervals are $0.05 \mathrm{psu}$. The areas where the climatology is saltier than the model are shaded. (right) Three year mean of simulation; the contour intervals in psu are $[34.8,35.5,35.8,35.85,35.9,35.95,35.98,36,36.02,36.05,36.1,36.15,36.2,36.25,36.3]$. 


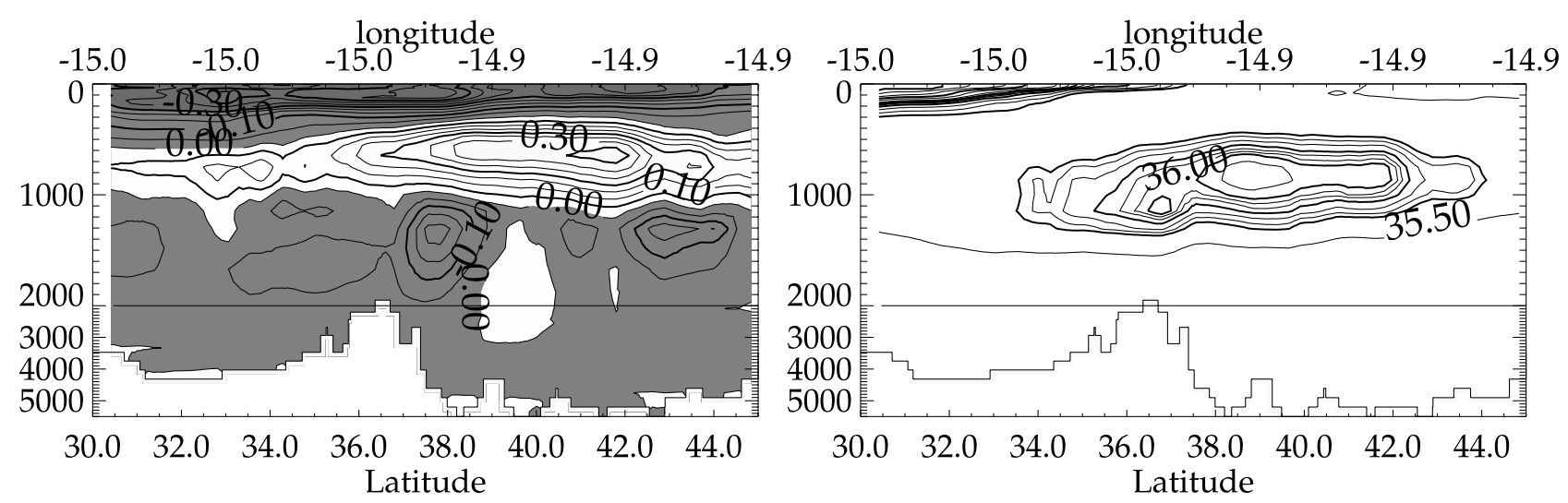

Figure 4. Salinity section (branch 2 (see Figure 2 )) at $15^{\circ} \mathrm{W}$. (left) Three year mean of simulation minus climatology; the contour intervals are $0.05 \mathrm{psu}$. The areas where the climatology is saltier than the model are shaded. (right) Three year mean of simulation; the contour intervals in psu are [34.8, 35.5, 35.8, $35.85,35.9,35.95,35.98,36,36.02,36.05,36.1,36.15,36.2,36.25,36.3]$.

less, the simulation duration is too short to follow the meddies in the western part of the Atlantic.

\section{Mediterranean Water Outflow}

\subsection{High-Salinity Tongue Extension}

[11] The MW salinity extension in the Atlantic Ocean has been intensively studied in the past. See for example the review of the subject by Iorga and Lozier [1999a]. The salty MW sinks under the Atlantic water west of the strait of Gibraltar. The MW stabilizes at around $1000-1200 \mathrm{~m}$ in the Gulf of Cadiz, which is the level of neutral buoyancy.

[12] With the slight relaxation constraint described in section 2, the model can reproduce realistically enough the MW circulation in the northeast Atlantic. At $870 \mathrm{~m}$ (Figure 2) and $1100 \mathrm{~m}$ (not shown) the salinity field reveals the extension of the MW tongue in the model and in the Reynaud climatology. In the real world, the westward highsalinity core $(>35.8 \mathrm{psu})$ propagation extends toward $25^{\circ} \mathrm{W}$ at $870 \mathrm{~m}$ and more than $20^{\circ} \mathrm{W}$ at $1100 \mathrm{~m}$ (Reynaud climatology and Iorga and Lozier [1999b]). In the model, the westward penetration of the MW tongue is greater than observed at $870 \mathrm{~m}$ and weaker at $1100 \mathrm{~m}$.

[13] In the northern direction the salty water follows the European continental shelf of the Bay of Biscay (salinity > $35.8 \mathrm{psu}$ ) up to $50^{\circ} \mathrm{N}$ (salinity $>35.5 \mathrm{psu}$ ). At Cape Finisterre the previous problem is also present with an excess of salty water at $870 \mathrm{~m}$ and a deficit at $1100 \mathrm{~m}$. However, this salinity bias is very small compared to the observations $(<0.05 \mathrm{psu})$; and the boundary of the MW (35.5 psu contour in Figure 2) is similarly located around $32^{\circ} \mathrm{W}$ and $52^{\circ} \mathrm{N}$ at $870 \mathrm{~m}$, and around $29^{\circ} \mathrm{W}$ and $49^{\circ} \mathrm{N}$ at $1100 \mathrm{~m}$, both in the model and the climatology.

[14] The first maximum of salinity is situated above $700 \mathrm{~m}$ (Figure 3), corresponding to the MW vein which follows the Portuguese shelf. Although this MW vein does not exist in the climatology, this result is in good agreement with the MW properties measured during the "SEMANE 99" cruise
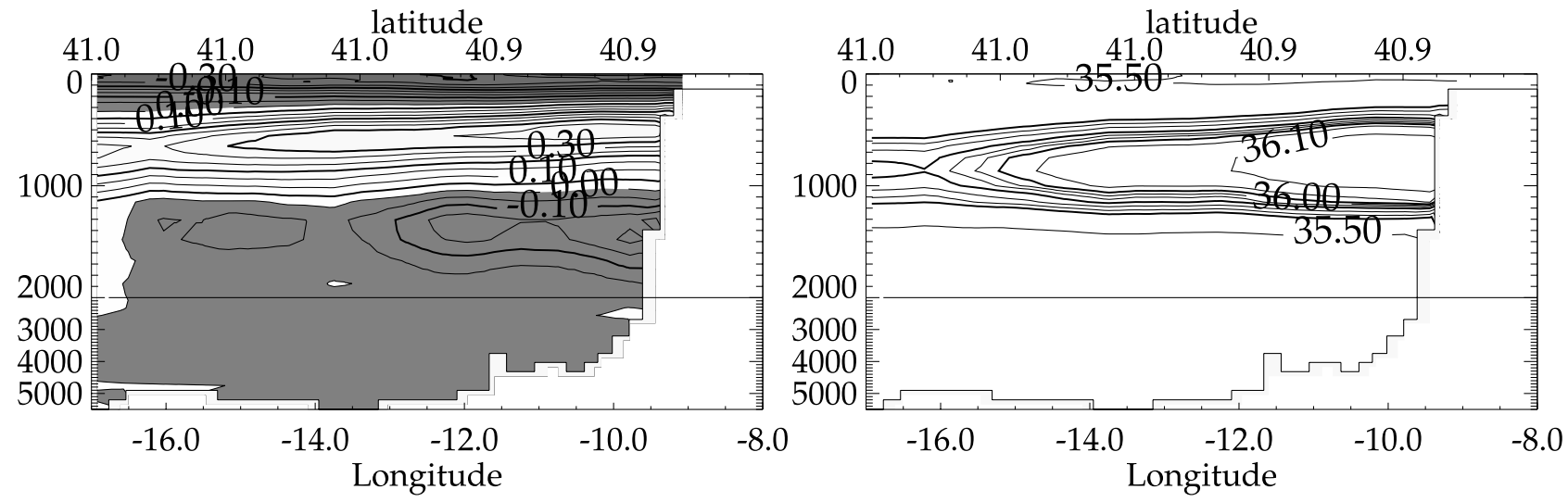

Figure 5. Salinity section (branch 3 (see Figure 2)) at $41^{\circ} \mathrm{N}$ along the Portuguese coast. (left) Three year mean of simulation minus climatology; the contour intervals are 0.05 psu. The areas where the climatology is saltier than the model are shaded. (right) Three year mean of simulation; the contour intervals in psu are $[34.8,35.5,35.8,35.85,35.9,35.95,35.98,36,36.02,36.05,36.1,36.15,36.2,36.25$, 36.3]. 

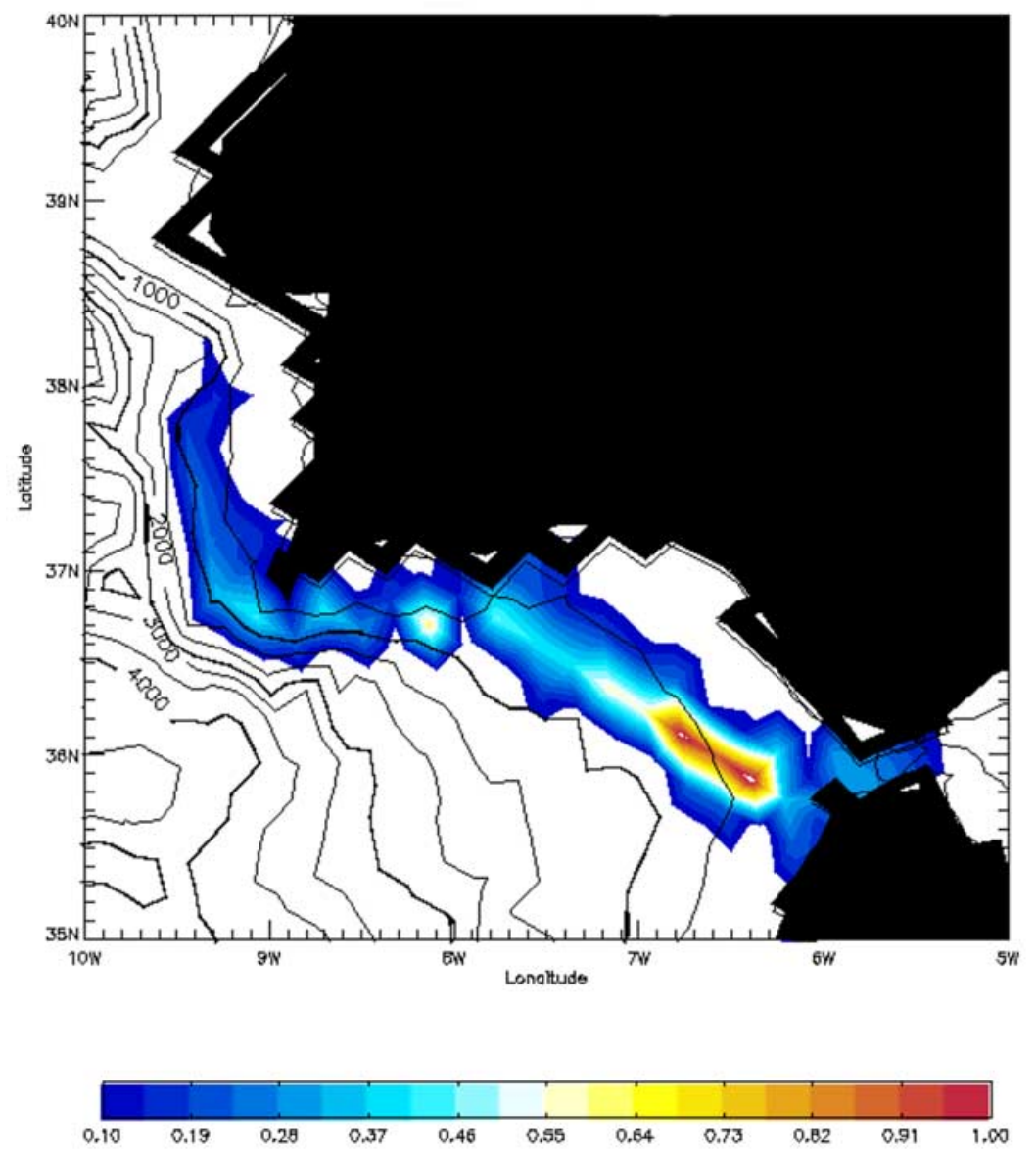

Figure 6. Five day mean of the bottom velocity (color field) in meters per second in August 2002. The contour lines are the bathymetry in meters.

[Talandier et al., 2001] which give a salinity of $36.2 \mathrm{psu}$ and a temperature of $12^{\circ} \mathrm{C}$ at around $650 \mathrm{~m}$ along the shelf at $8.3^{\circ} \mathrm{W}, 36.7^{\circ} \mathrm{N}$. It is also important to note that the Reynaud climatology is colder $\left(1.5^{\circ} \mathrm{C}\right)$ and fresher $(0.2 \mathrm{psu})$ compared to the "SEMANE 99" observations at the Gibraltar output. The thin coastal MW (Figure 3) vein along the Spanish shelf $(\sim 650 \mathrm{~m})$ does not exist in the climatology the presence of this vein explains some model bias described later in section 4.3. The principal MW vein follows the $1000 \mathrm{~m}$ depth referenced isodensity $32.2 \mathrm{~kg} \mathrm{~m}^{-3}$ line in both model and climatology, in a layer between 1100 and $1200 \mathrm{~m}$. The vein salinity exceeds $36.25 \mathrm{psu}$ in the climatology and the maximum of the modeled vein salinity remains less than 36.2 psu.

[15] The $15^{\circ} \mathrm{W}$ section (Figure 4) shows a northward displacement of the salinity maximum, the vein is also lifted into upper layers of the water column. The explanation could be the principal MW vein separate from the coast at Tejo Plato in the simulation instead of at Cape St. Vincent in the observation. The vein is also lifted into upper layers of the water column because of salinity and so density deficit at the source of the MW vein in the Gulf of Cadiz. Following the MW in the north direction, south of Cape Finisterre (Figure 5) and also along the continental shelf in the Bay of Biscay (not shown), the vertical extension of the vein is larger in the model compared to the climatology, and the salinity maximum, around $36.1 \mathrm{psu}$, is higher in the water column.

\subsection{Dynamics of the Mediterranean Water Mass}

[16] The MW characterized by temperature and salinity fields seems to spreads out uniformly in the Atlantic Ocean. The study of the MW vein dynamics allows us to identify four branches of MW.

[17] The water vein going through the Gibraltar Strait and the Gulf of Cadiz is the source of the MW in the Atlantic Ocean. Current observations give an evaluation of transport intensity through the Gibraltar Strait between 0.6 and $1.2 \mathrm{~Sv}$. In the simulation, described in section 2 , the 4 year mean transport of MW through the Gibraltar Strait is $0.84 \mathrm{~Sv}$ with instantaneous values between $0.5 \mathrm{~Sv}$ and $1.2 \mathrm{~Sv}$. This value is in good agreement with the estimation by Johnson et al. [1994] (0.9 Sv) or Hopkins [1999] (0.84 Sv). The velocity of the MW at the bottom of the Gibraltar Strait (Figure 6) is around $15 \mathrm{~cm} \mathrm{~s}^{-1}$ in the PAM model, which is very similar to the estimation of $14 \mathrm{~cm} \mathrm{~s}^{-1}$ by Iorga and Lozier [1999b].

[18] The bottom horizontal velocity of the MW reaches a maximum between the sill of the Gibraltar Strait and $700 \mathrm{~m}$ depth in an area centered at $6.5^{\circ} \mathrm{W}, 36^{\circ} \mathrm{N}$. In the area, the maximum velocity ranges between 0.7 and $1 \mathrm{~m} \mathrm{~s}^{-1}$, the 


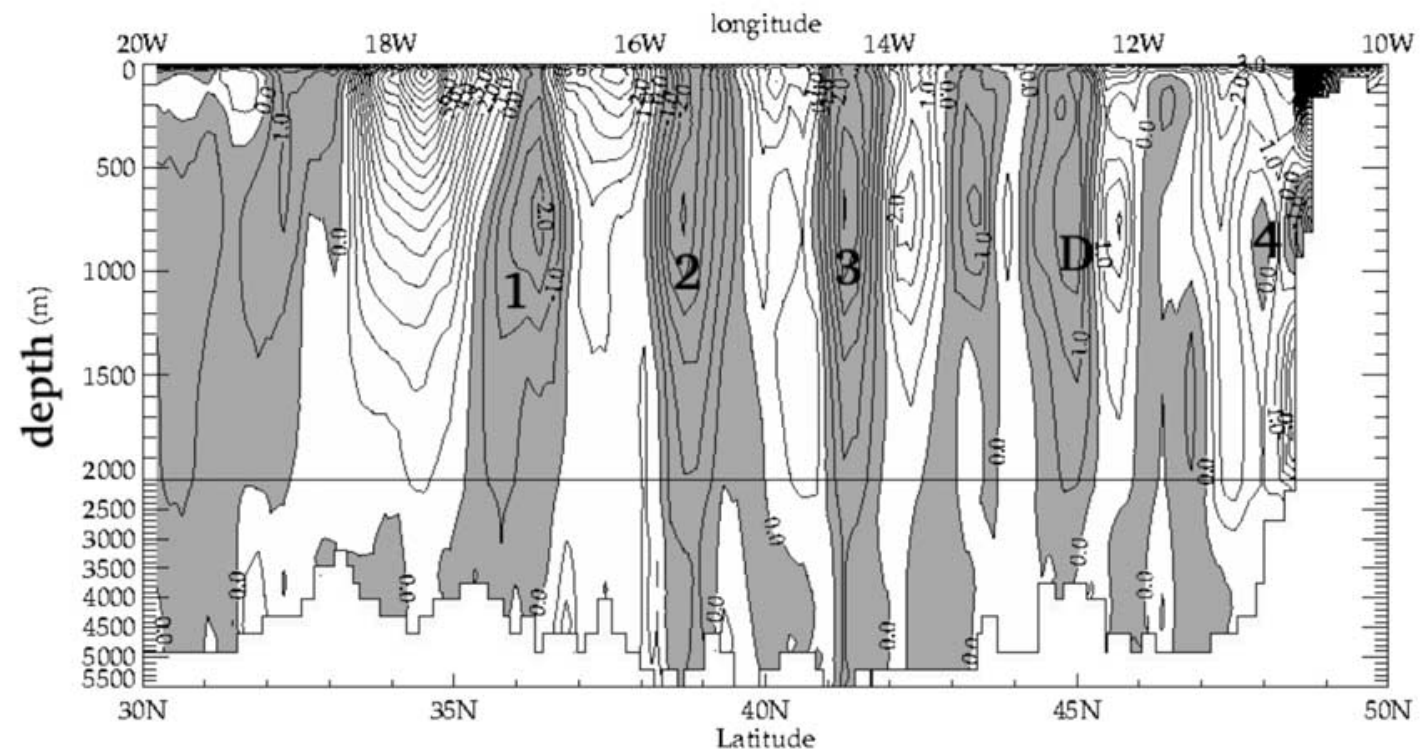

Figure 7. The cross 3 year mean $\left[20^{\circ} \mathrm{W}, 30^{\circ} \mathrm{N}-10^{\circ} \mathrm{W}, 50^{\circ} \mathrm{N}\right]$ section velocity $\left(\mathrm{cm} \mathrm{s}^{-1}\right)$. The shaded contours are the eastward velocity. The four Mediterranean Water (MW) veins described in section 3.2 are numbered in this section.

modeled MW water plume pattern resembles, that described by Johnson et al. [1994]. The authors indicate a maximum of velocity around $1 \mathrm{~m} \mathrm{~s}^{-1}$ situated at $6.6^{\circ} \mathrm{W}$, $35.75^{\circ} \mathrm{N}$ between the isobaths $400 \mathrm{~m}$ and $600 \mathrm{~m}$. In the model, the maximum velocity is around $50 \mathrm{~cm} \mathrm{~s}^{-1}$ weaker between $7^{\circ} \mathrm{W}$ and $9^{\circ} \mathrm{W}$ in a layer bounded by $500 \mathrm{~m}$ and $1000 \mathrm{~m}$. In agreement with the estimation made by Bower et al. [2002], the velocity slows down to around $15 \mathrm{~cm} \mathrm{~s}^{-1}$ downstream of Cape St. Vincent at $1000 \mathrm{~m}$.

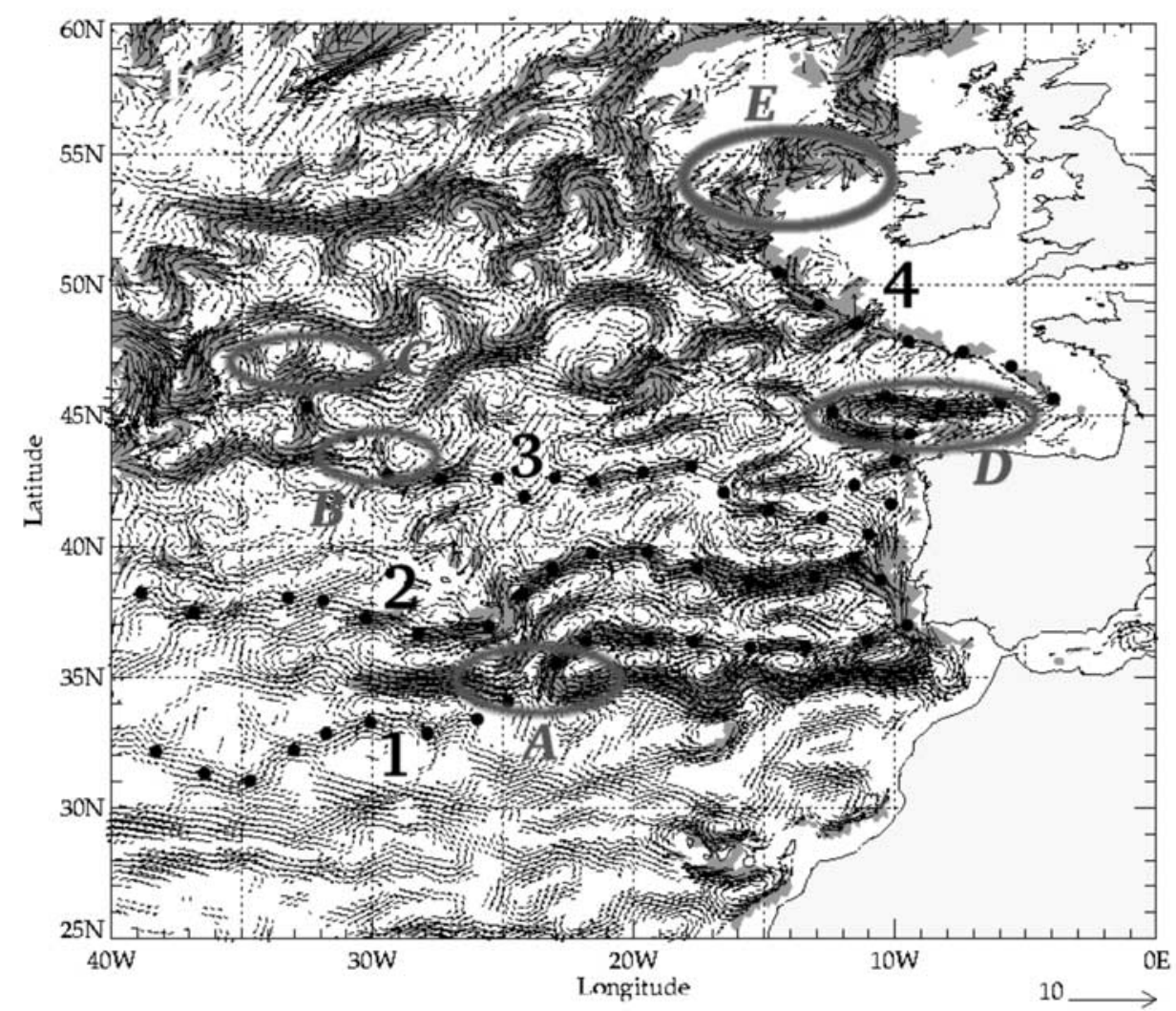

Figure 8. Three year mean velocity $\left(\mathrm{cm} \mathrm{s}^{-1}\right)$ at $870 \mathrm{~m}$ depth. The shaded area shows the higher velocities $\left(>2.0 \mathrm{~cm} \mathrm{~s}^{-1}\right)$. The dotted lines show the mean pathway of the four main MW veins. The encircled areas A, B, C, D, and E are described in section 3.2. 

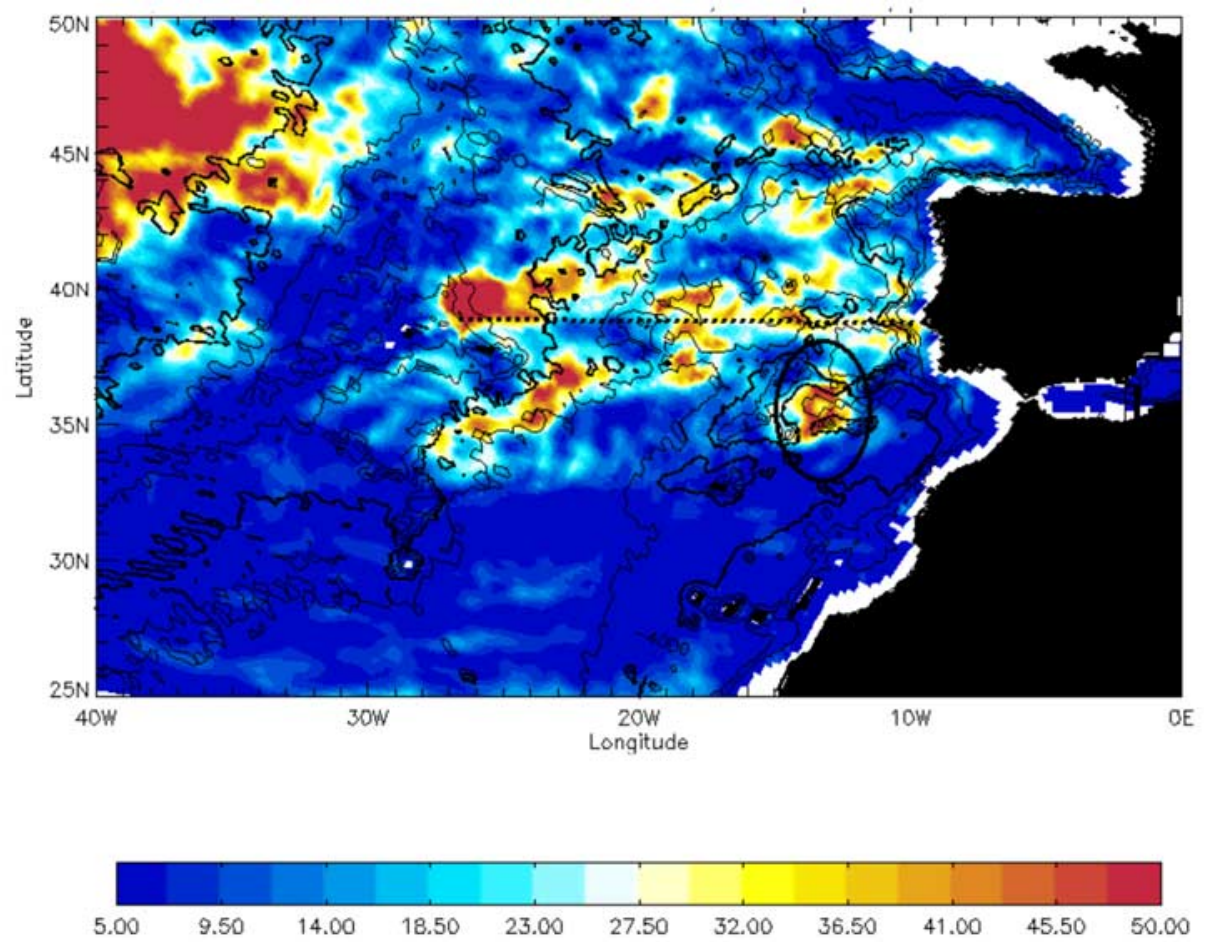

Figure 9. Eddy kinetic energy $\left(\mathrm{m}^{2} \mathrm{~s}^{-2}\right)$ at $868 \mathrm{~m}$ computed for 2001. For the dashed line and encircled areas, see the text for comments in section 4.2.

[19] In a first approximation, the MW is advected westward. Several methods have been used in the model to estimate the mean westward velocity during the simulation, to study the mean velocity through a vertical section (Figure 7) in the MW or to study the Lagrangian trajectories. The vertical section (Figure 7) shows the different modeled MW branches described in the following subsections.

[20] Iorga and Lozier [1999b] used the velocity field at isodensity 29.7 referenced at $500 \mathrm{~m}$ (approximately $870 \mathrm{~m}$ in the model) and 29.9 (approximately $1145 \mathrm{~m}$ in the model) to characterize the MW vein. This vein splits into two branches at Cape St. Vincent, a first one identified as a zonal current constrained between $35.5^{\circ} \mathrm{N}$ and $36.5^{\circ} \mathrm{N}$, and a second as a slope coastal current along the European shelf until Ireland. Bower et al. [2002] compute the mean velocity and the Eddy kinetic energy in the Cape St. Vincent and Tejo Plato area using non meddy float data and define a similar MW pathway adding nevertheless a low-intensity zonal current in front of Tejo Plato.

[21] As discussed in the following subsections, the southern branch is well represented by the model, but the northern branch splits into three branches in the simulation. Three of the model branches (the southern one (branch 1), the middle one (branch 2), and the first northern one (branch 3) (see Figure 8)) exhibit meddy formation area. The advection of the meddies along these three routes explains a large part of the velocity intensity in these branches.

\subsubsection{Southern Branch}

[22] The southern branch of MW leaves the coast off Cape St. Vincent in the western direction at $36^{\circ} \mathrm{N}$ (branch 1 (Figure 8)). Eastward of $23^{\circ} \mathrm{W}$, the current is predominantly zonal with a mean velocity around $2.0 \mathrm{~cm} \mathrm{~s}^{-1}$ (Figures 7 and 8) centered at $750 \mathrm{~m}$ depth and a very low EKE (Figure 9). In the observation [Bower et al., 2002; Iorga and Lozier, 1999b], but also in low-resolution model (not shown), this branch is the principal one, it transports MW westward in the Atlantic Ocean even the meddies are not take into account. Bower et al. [2002] shows a first maximum in front of Cape St. Vincent with velocity greater than $10.0 \mathrm{~cm} \mathrm{~s}^{-1}$ and EKE greater than $100.0 \mathrm{~cm}^{2} \mathrm{~s}^{-2}$ which is not present in our simulation.

[23] Westward of $23^{\circ} \mathrm{W}$, this branch meets the end of the Azores current (area A, Figure 8) coming from the west and going into the Gulf of Cadiz. The mean velocity of this first MW branch is between 0.9 and $1.5 \mathrm{~cm} \mathrm{~s}^{-1}$ at $870 \mathrm{~m}$ depth (Figure 8); this mean velocity decreases slightly with depth in the vein (not shown). When the southern branch meets the Azores Current $\left(23^{\circ} \mathrm{W} 35^{\circ} \mathrm{N}\right)$, the vein is shifted toward the southwest direction, reaching $40^{\circ} \mathrm{W}$ between 30 and $33^{\circ} \mathrm{N}$ at $0.8 \mathrm{~cm} \mathrm{~s}^{-1}$ mean speed. The continuity of this current is not viewable in Figure 8 but several floats launched in this experiment effectively cross the $33^{\circ} \mathrm{N}$ latitude line at a longitude between $15^{\circ}$ and $30^{\circ} \mathrm{W}$. Sparrow et al. [2002] exhibit also a southwest bifurcation of this southern branch west of the Horseshoe Seamounts around $20^{\circ}-25^{\circ} \mathrm{W}$. The EKE (Figure 9) is in this area relatively large $\left(50 \mathrm{~cm}^{2} \mathrm{~s}^{-2}\right)$ in the simulation which indicates a meddy pathway along the western part of the branch 1 .

\subsubsection{Middle Branch}

[24] North of the separation of the southern branch and the main vein, between Cape St. Vincent and Tejo Plato, the mean coastal current reaches large values $\left(>10.0 \mathrm{~cm} \mathrm{~s}^{-1}\right)$ with a maximum of $18.0 \mathrm{~cm} \mathrm{~s}^{-1}$ at $870 \mathrm{~m}$ in good 
agreement with Bower et al. [2002]. At $1100 \mathrm{~m}$ this current remains strong with a mean velocity greater than $3.0 \mathrm{~cm} \mathrm{~s}^{-1}$ and a maximum value of $5.0 \mathrm{~cm} \mathrm{~s}^{-1}$.

[25] Around Tejo Plato, the main MW vein in the PAM21 simulation separates from the coast (branch 2, Figure 8). Contrary to the branch 1 the mean velocity in this vein is more intense in this simulation than observations and the high EKE (dashed line, Figure 9) along the branch 2 indicates the main meddy pathway. Bower et al. [2002], using non meddy float data, exhibit a really low intense westward MW vein in front of Tejo Plato, this vein is also missing in low-resolution model (not shown), that proves the branch 2 is principally due to the meddy pathway. The zonal current at $39^{\circ} \mathrm{N}$ has a westward direction west of $24^{\circ} \mathrm{W}$ with a velocity of $2.0-3.0 \mathrm{~cm} \mathrm{~s}^{-1}$ at $870 \mathrm{~m}$. There, the current follows the topography of the Azores Seamounts to take a southward direction. South of the Azores Seamounts around $36^{\circ} \mathrm{N}$, the current velocities decrease $\left(<1.0 \mathrm{~cm} \mathrm{~s}^{-1}\right)$ and cross the Atlantic Ridge through rifts. This mean current seems to be continuous between the European coast and the middle of the Atlantic Ocean, but mixing and diffusive processes have dissipated the salinity anomaly.

\subsubsection{Two Northern Branches}

[26] In the northern part of the MW pathway a new separation occurs around Cape Finisterre (branch 3, Figures 7 and 8) and the main vein enters into the Bay of Biscay (branch 4, Figures 7 and 8) and follows the European shelf until Ireland. The third separated branch has a westward direction with a velocity between 1.0 and $3.0 \mathrm{~cm} \mathrm{~s}^{-1}$ at $870 \mathrm{~m}$ depth and the EKE along this branch (Figure 9) indicates the pathway of the meddies created around the Finistere Cape. The branch is blocked by the strong North Atlantic current around $43^{\circ} \mathrm{N}$ (areas B and C, Figure 8).

[27] The mean pathway of the MW penetrating into the Bay of Biscay is also constrained by topographic structures. At Cape Finisterre the current leaves the coast in the western direction and makes a loop around the Charcot Seamounts and the Biscay Seamount before entering the Bay (area D area, Figures 7 and 8). The current seems to induce a closed circulation in the south of the Bay of Biscay with a westward current following the Spanish coast south of the Biscay Seamount.

[28] The coastal northward current is more intense at $870 \mathrm{~m}$ than at $1100 \mathrm{~m}, 2.5 \mathrm{~cm} \mathrm{~s}^{-1}$ versus $1.0 \mathrm{~cm} \mathrm{~s}^{-1}$ along the French shelf. In the Iorga and Lozier [1999b] description this coastal current seems to be more intense $\left(3.0-4.0 \mathrm{~cm} \mathrm{~s}^{-1}\right)$ and does not decrease with the depth. Like branch 3 , branch 4 joins the North Atlantic current off Ireland between $50^{\circ}$ and $55^{\circ} \mathrm{N}$ (area E, Figure 8).

\section{Meddies}

\subsection{Methods for Meddy Detection in the Model}

[29] Four different criteria based on different model outputs are used to detect and study a meddy in the model.

[30] 1. The first consists in identifying directly the meddy pattern in the 3-D salinity and temperature field. In the subsequent horizontal and vertical sections, the meddy is spotted through its thermohaline properties, i.e., where the gradient is strongly localized. This method is used in section 4.3.1 to study six modeled meddies at a chosen date and location.

[31] 2. The second method uses float trajectories computed in the model to select the meddies. The floats are initialized in the whole domain in January 2001 on a horizontal grid with $1^{\circ}$ resolution and at the vertical levels $56 \mathrm{~m}, 102 \mathrm{~m}, 473 \mathrm{~m}, 867 \mathrm{~m}, 1874 \mathrm{~m}$, and $2809 \mathrm{~m}$. They are advected with the 3-D model velocities for 1.5 years; their positions, salinities, temperatures and velocities are stored every day. A first sort is performed to select the floats which are in the MW at a specified date. The criteria for this selection are: salinity between 35.7 and 36.5 psu; position in the $3-\mathrm{D}$ box bounded by $15^{\circ} \mathrm{W}, 8^{\circ} \mathrm{W}, 35^{\circ} \mathrm{N}$, and $45^{\circ} \mathrm{N}$; and depth between 600 and $1880 \mathrm{~m}$. To differentiate the floats trapped in a meddy from a float in the MW, a velocity criterion is used. In the MW, a velocity greater than $8.0 \mathrm{~cm} \mathrm{~s}^{-1}$ is always in a meddy, because in the MW vein the velocities are always much lower.

[32] 3. The third method is an automatic counting of the meddies performed on the salinity field at $870 \mathrm{~m}$. A coastal box limited by $9,13^{\circ} \mathrm{W}$ and $37,44^{\circ} \mathrm{N}$ has been omitted from the counting: in this area the meddies are not separated from the MW vein, and the structures detected with the algorithm are not meddies but salinity fronts. The criterion of detection is based on a gradient of salinity greater than $0.15 \mathrm{psu}$ in all directions around each point where salinity is greater than $35.95 \mathrm{psu}$. This detection is performed on a salinity field sampled on a coarser grid (one point over the four original grid points). The horizontal sampled precision is then approximately $20 \mathrm{~km}$. After a selection, the points which satisfy the criterion are merged with their neighbors and an ellipsoid including all these points is computed. In the size classification the smallest meddies have a radius less than $25 \mathrm{~km}$, so they are represented by four meshes of the subsampling field or 64 meshes with the model resolution. In any case eight points in each direction are large enough to resolve mesoscale structures.

[33] 4. Finally, a vertical section of salinity and its normal velocity are used to compute the anomaly salinity transport between 475 and $1670 \mathrm{~m}$. At each model level the mean salinity is computed along the section and the meddies are detected for each grid point where the anomaly salinity is greater than $0.4 \mathrm{psu}$.

\subsection{Formation of the Meddies}

[34] The formation of the meddies has been studied with analytical and numerical methods [Aiki and Yamagata, 2004; Beckmann and Käse, 1989; Colin de Verdière, 1992; Dewar, 2002; Jungclaus, 1999; Killworth, 1986; Morel, 1995; Morel and McWilliams, 1997; Pichevin and Nof, 1996]. For example, Pichevin and Nof [1996] describe the eddy formation in an idealized case of a dense water current (the MW), following a wall on its right (the southern Spanish coast, west of the Gibraltar Strait) and arriving on a zonal Cape (Cape St. Vincent). The current goes round the cape and the Coriolis force constrains the flow to the northward direction. In their configuration, the stationary state is continually perturbed by the formation and westward advection of eddies. These cases are especially encountered in our three meddy formation areas detected in the model, which are Cape St. Vincent, Tejo Plato, and Cape Finisterre. In the simulation, the Tejo Plato plays the main 
Table 1. Characteristics of Six Model Meddies Distributed Over the Whole Domain at the End of August 2002 in the Simulation and Two Meddies Observed During Cruises ${ }^{\mathrm{a}}$

\begin{tabular}{|c|c|c|c|c|c|}
\hline Branch No. & Position, ${ }^{\circ} \mathrm{W}-{ }^{\circ} \mathrm{C}$ & Maximum Salinity, psu & Maximum Temperature, ${ }^{\circ} \mathrm{C}$ & Radius, km & Thickness, $\mathrm{m}$ \\
\hline M2 & $20-38$ & 36.18 & 11.9 & 85 & 1200 \\
\hline M4 & $15.5-43.5$ & 36.15 & 11.8 & 110 & 700 \\
\hline M5 & $30.5-35$ & 36.17 & 12.0 & 40 & 700 \\
\hline M6 & $16-46$ & 36.00 & 11.4 & 25 & 600 \\
\hline
\end{tabular}

${ }^{\mathrm{a}}$ Horizontal and vertical sections of the simulated meddies are plotted in Figure 10.

role in the meddy formation rather than the usual Cape St. Vincent.

[35] The Eddy Kinetic Energy field (EKE) (Figure 9) computed for the 2001 at $870 \mathrm{~m}$, exhibits a maximum of turbulence in front of Tejo Plato. This maximum follows a zonal front at $39^{\circ} \mathrm{N}$ in the westward direction (dashed line, Figure 9), which identifies the main formation area and advection route for the meddies. A southwest tongue of intense EKE is also detected, which indicates that some meddies, formed at the Tejo Plato are advected in the Horseshoe Seamounts area (encircled area, Figure 9). Bower et al. [2002] have computed the EKE with the float data around Cape St. Vincent and Tejo Plato, they exhibit two maxima with the more intense at Cape St. Vincent (EKE > $100 \mathrm{~cm}^{2} \mathrm{~s}^{-2}$ ) and the second one at Tejo Plato (EKE > $50 \mathrm{~cm}^{2} \mathrm{~s}^{-2}$ ). In PAM21 simulation the EKE is quite well represented in front of Tejo Plato with values around $50 \mathrm{~cm}^{2} \mathrm{~s}^{-2}$ but the Cape St. Vincent does not play the main role like described with observations. Cape Finisterre plays the same role as Tejo Plato, with a topographic perturbation of the northward coastal current which separates from the coast at the cape and is advected in the westward direction.

\subsection{Thermohaline Structures of the Meddies}

[36] The description of the thermohaline structure of the simulated meddies is based first on the vertical temperature and salinity sections crossing the meddies on a 5 day mean field. Second, float trajectories are followed to get the temporal evolution of the 3-D field. We illustrate the study with six meddies found in the 5 day mean field and four float trajectories extracted from 206 encountered in the MW during the simulation. The six meddies described in section 4.3.1 are different from those found in the four trajectories described in section 4.3.2.

\subsubsection{Instantaneous Vision}

[37] To study the thermohaline structure of the simulated meddies, six coherent eddies were chosen in the MW tongue at the end of August 2002. They represent all the different types of eddies simulated by the model in the MW with different sizes, spread over a large geographical area. Five anticyclonic structures (M1, M2, M4, M5, and M6) and one cyclonic (M3) were selected (Table 1).

[38] A meddy usually has an anticyclonic circulation; the five studied here have a radius between 25 and $110 \mathrm{~km}$ and a thickness between 600 and $1200 \mathrm{~m}$. The size of their structures is in agreement with the meddies observed during the Amuse and Semaphore cruise [Richardson et al., 2000], whose radii range from 20 to
$80 \mathrm{~km}$. Their vertical thickness varies between 800 and $1400 \mathrm{~m}$, with the core of the structures located at a depth around $1000 \mathrm{~m}$ [Richardson et al., 2000]. Another meddy, called Hyperion, observed in July 1993 [Tychensky and Carton, 1998] also had a radius of $60 \mathrm{~km}$ and a thickness of $900 \mathrm{~m}$ (Table 1).

[39] The observed meddies are found $100 \mathrm{~m}$ deeper (around one model level at that depth) than the simulated ones. The difference between the depth of the temperature maximum and the depth of the salinity maximum is nevertheless well represented in the model. The salinity maximum is always deeper than the temperature maximum. This difference is $200-300 \mathrm{~m}$ in the observation and $100-150 \mathrm{~m}$ in the simulation. The two salinity maxima in the observed meddies are never captured by the model. The meddy temperature maximum (Figure 10) is $11.8^{\circ}-11.9^{\circ} \mathrm{C}$ and their salinity maximum is $36.1-36.2 \mathrm{psu}$. The temperature difference between the core of the meddy and its surrounding water is $1^{\circ}-2^{\circ} \mathrm{C}$, and the salinity difference is $0.5-$ 0.6 psu. Compared to the observations, south of $40^{\circ} \mathrm{N}$, the PAM simulated meddies are too cold and too fresh by $0.7^{\circ} \mathrm{C}$ and $0.2 \mathrm{psu}$. This bias in the thermohaline structure of the meddies is probably due to the deep climatological data relaxation described in section 2 . We already mentioned in section 3 that the coastal MW current along the Spanish shelf is not present in the climatology. This vein should be saltier $(+0.2 \mathrm{psu})$ and warmer $\left(+1.5^{\circ} \mathrm{C}\right)$ before the Cape St. Vincent. The meddies formed by the vein are thus fresher and colder in the model.

[40] The northern meddies (M4 and M6) have temperature and salinity properties in accordance with the observations. Paillet et al. [2002] described a northern meddy, called Ulla (Table 1), situated at $12^{\circ} \mathrm{W}, 45^{\circ} \mathrm{N}$, which has a temperature maximum of $11.5^{\circ} \mathrm{C}$, a salinity maximum of $36.15 \mathrm{psu}$, a zonal radius of $30 \mathrm{~km}$, and a meridional radius of $20 \mathrm{~km}$. These values are in good agreement with meddy M6 in the model (Table 1). The vertical extension of meddy M6 $(600 \mathrm{~m})$ is also in good agreement with the observed one $(700 \mathrm{~m})$.

[41] Cyclonic eddies have been less frequently observed [Richardson and Tychensky, 1998] but are largely simulated by different models. M3 is a small structure and has temperature and salinity gradients $\left(0.5^{\circ} \mathrm{C}\right.$ and $\left.0.1 \mathrm{psu}\right)$ weaker than the anticyclonic as in previous studies, and our cyclonic eddies are often coupled with the anticyclonic ones and form a sort of dipole.

\subsubsection{Spatiotemporal Variability}

[42] The study of four particular meddies allows us to describe the spatiotemporal variability of the thermohaline 

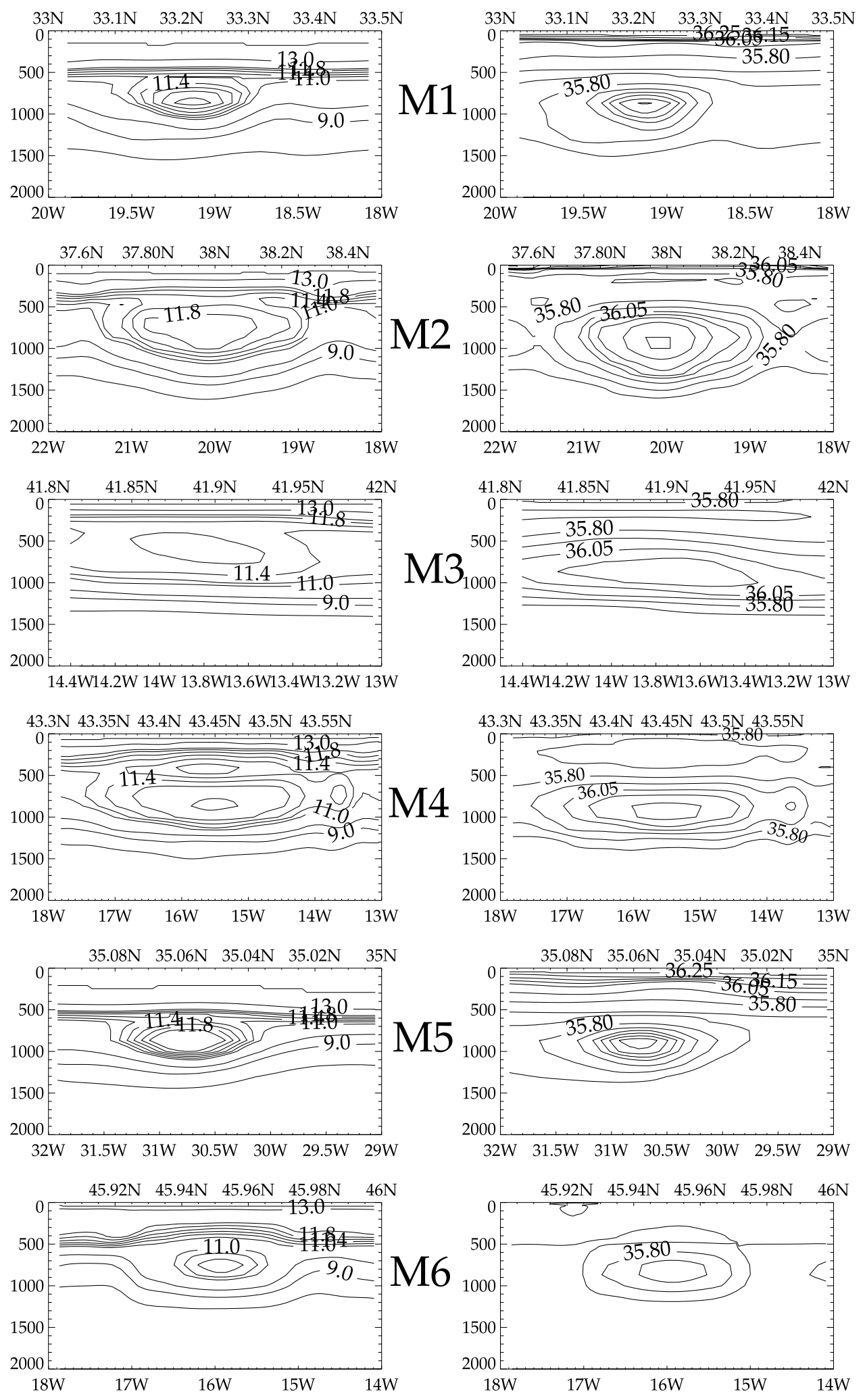

Figure 10. (left) Temperature in ${ }^{\circ} \mathrm{C}$ and (right) salinity in psu across six eddies. The third eddy is a cyclonic, and the other five are meddies. Contour levels for the temperature are $[5,7,9,10,11,11.2,11.6$, $11.8,12,13,15]$, and for the salinity the contour levels are $[35.4,35.6,35.8,35.95,36,36.05,36.1$, $36.15,36.2,36.25]$. 

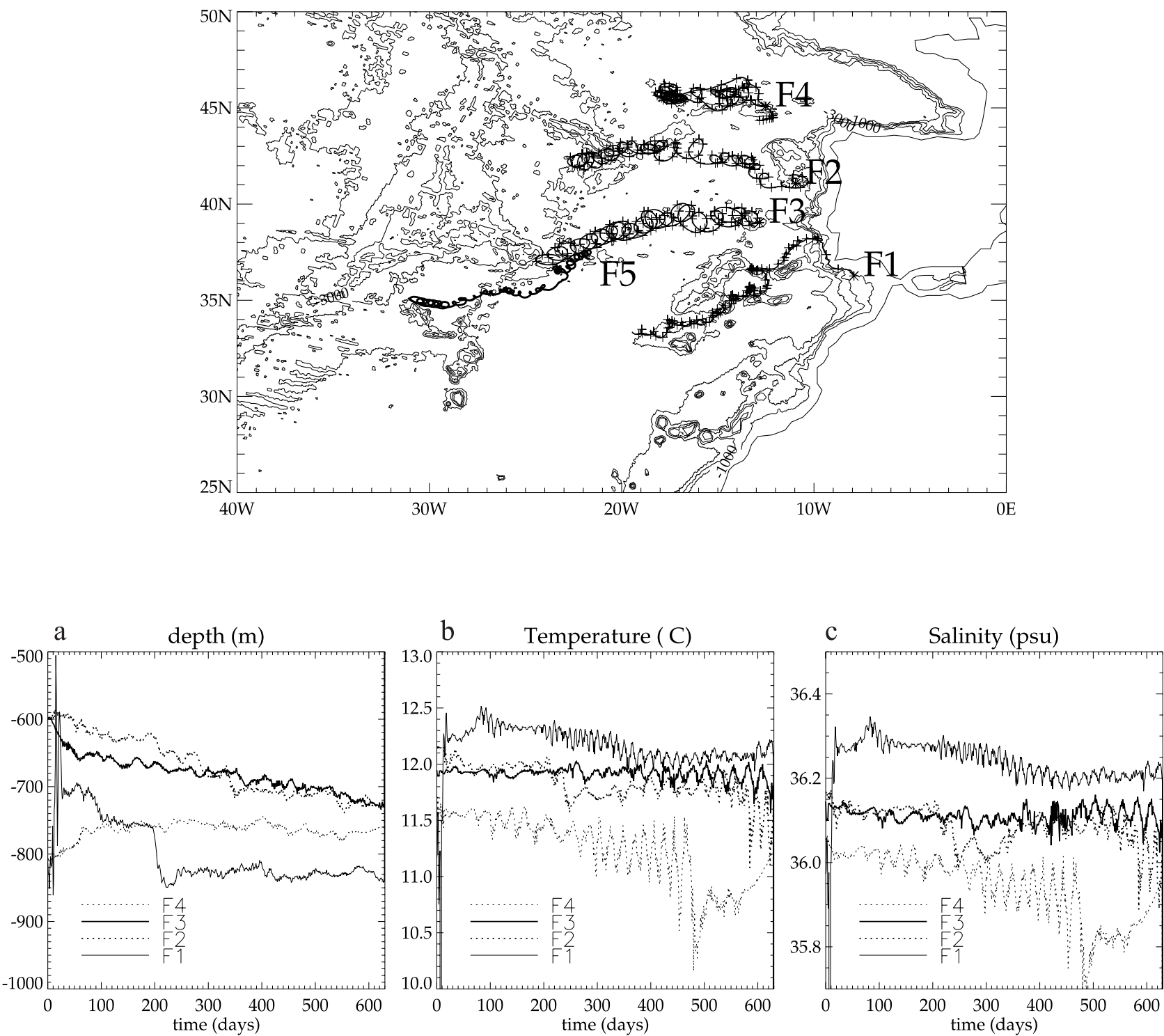

Figure 11. (top) Twenty months of floats trajectories trapped in four different meddies. Across every week is plotted on the trajectory. The three bottom temporal series represent the evolution of the (a) depth, (b) temperature, and (c) salinity along the four float trajectories.

structure in a meddy. Figure 11 shows the trajectories of five floats caught in the five meddies. The evolution of the salinity along the four trajectories (F1, F2, F3, and F4) can be explained by: the change due to the dissipation or interaction with the bathymetry, a current or another eddy, the horizontal or the vertical position of the floats in the meddy or their expulsion from it.

[43] The horizontal displacement of the floats is correlated to their position in the meddy: floats near the centre (respectively the edge) are represented by small (respectively large) loops. Figures $11 \mathrm{a}, 11 \mathrm{~b}$, and $11 \mathrm{c}$ show the temporal evolution of the vertical displacement of the floats.

[44] For float $\mathrm{F} 1$, around $35^{\circ} \mathrm{N}$, the mean salinity along the trajectory is 36.23 psu with a standard deviation of 0.05 . The salinity decreases slightly between February 2001 and August 2002. During this period the meddy is advected in the Horseshoe Seamounts area where the topography perturbs its trajectory, and its salinity which weakens from
36.32 to $36.17 \mathrm{psu}$. This slight decrease in salinity is contrasted with the fast sinking of the float, which is situated around $720 \mathrm{~m}$ before the Horseshoe Seamounts and around $850 \mathrm{~m}$ afterward.

[45] Float F3, located around $38^{\circ}-39^{\circ} \mathrm{N}$, is advected in the western direction toward $19^{\circ} \mathrm{W}$ and in the southwest direction afterward. Salinity variations between the beginning and the end of the trajectory are very small (standard deviation of $0.02 \mathrm{psu}$ ) compared to the mean value $(36.11 \mathrm{psu})$. Where there is no topographic perturbation, no interaction between several meddies and no interaction with another current, the diffusion affects only slightly the robust characteristics of the meddy for several months.

[46] Float F2, around $43^{\circ} \mathrm{N}$, is advected in the northwest direction but remains south of Cape Finisterre, with a mean salinity of $36.08 \mathrm{psu}$ and a standard deviation of $0.05 \mathrm{psu}$ during the trajectory. The loss of salinity observed at the end 


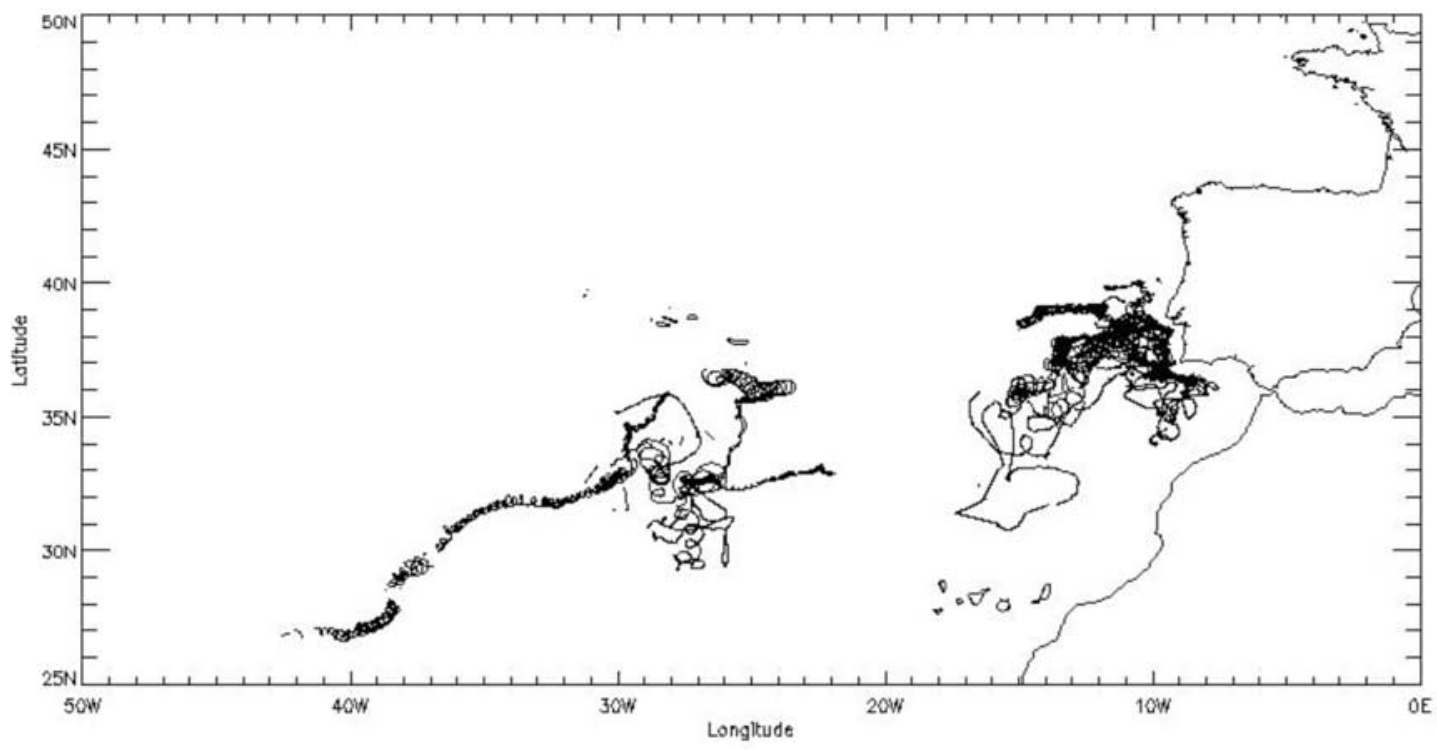

Figure 12. Float trajectories during Amuse and Semaphore cruise in 1993-1994.

of the simulation $(-0.2 \mathrm{psu})$ is explained here by the interaction with another current. This time, the end of the strong North Atlantic current increases the mixing of the meddy with surrounding waters.

[47] The Charcot and Biscay seamounts also perturb the meddy north of $45^{\circ} \mathrm{N}(\mathrm{F} 4)$ and the variations are principally explained by the expulsion of the float from the meddy after 15 months of advection. The mean salinity of $35.94 \mathrm{psu}$ (35.97 psu when the float is in the meddy) is smaller compared to other meddies; the standard deviation of $0.08 \mathrm{psu}$ ( $0.05 \mathrm{psu}$ when the float is in the meddy) is larger than in the other cases. This case would be similar to the floats F2 and F3 if the period after the expulsion were omitted. This example highlights the difficulties in applying simple statistics to the float trajectories.

\subsection{Dynamics of the Meddies}

[48] The 5 year simulation is not long enough to follow all the simulated meddies throughout their life, but nevertheless some meddies are advected in the model for almost 4 years, and several for more than 1 year. This allows us to reach conclusions about relevant mean values (angular velocity, background or total velocities). The visual comparison between trajectories observed during Amuse and Semaphore cruises (Figure 12) and modeled trajectories (Figure 11) shows similarities: (1) formation of modeled meddies at St. Vincent Cape and Tejo Plato (F1 and F3, Figure 11); (2) advection of these meddies to the west and southwest direction; and (3) the end of the F5 travel after 5 years of simulation (Figure 11 ) around $30^{\circ} \mathrm{W}-35^{\circ} \mathrm{N}$ is a position where meddy have been observed during Semaphore cruise (Figure 12). In a longer simulation it will be really interesting to know if F5 float will be advected more westward like in the observation. This comparison shows also a couple differences: (1) observed meddy advected in the Gulf of Cadiz is never simulated and (2) the size of the loops is smaller in the observed compare to the simulated trajectories. This is also a indication that the simulated meddies are too large.

\subsubsection{Background and Total Velocity of the Meddies}

[49] In this section we compute a zonal or a meridional background velocity which is the velocity of one particle between two zonal or meridional sections supposing this trajectory is linear. The total velocity include the mesoscale activity, it is computed with the total distance along the trajectory between the two sections. The most westerly position of a meddy during this simulation is $34^{\circ} \mathrm{W}$ and is reached after 55 months of simulation (Figures $13 \mathrm{~b}$ and 11 (F5 trajectory)). This position is $2000 \mathrm{~km}$ from the meddy formation area. In this case, the westward background velocity is around $1.4 \mathrm{~cm} \mathrm{~s}^{-1}$ compared to $1 \mathrm{~cm} \mathrm{~s}^{-1}$ in the work of Arhan et al. [1994].

[50] The northern and southern meddies are not advected as far from the formation area as those drifting in the western directions. The most southern position seems to be around $32^{\circ} \mathrm{N}$, even if one meddy is detected at $30^{\circ} \mathrm{N}$ (Figure 13d), and the most northern position is between $46^{\circ} \mathrm{N}$ and $47^{\circ} \mathrm{N}$ (Figure 13c). So the largest southward advection is of the order of $500 \mathrm{~km}$ and the largest northward advection is $250 \mathrm{~km}$, by contrast to the westward direction for which the meddies are followed over the order of $2000 \mathrm{~km}$.

[51] Thanks to float trajectories, it is possible to separate the background velocity and the total velocity in the meddies. A selection of several floats is made with the following criteria: depths between 600 and $1600 \mathrm{~m}$, salinities between 35.7 and $36.5 \mathrm{psu}$, and the floats crossing the $15^{\circ} \mathrm{W}$ and the $20^{\circ} \mathrm{W}$ longitudes. For the 45 selected trajectories, the mean time to cover the $5^{\circ}$ distance is computed and gives the background westward velocity. The total distance covered by each float between these two lines is also calculated with the daily position. For the 45 trajectories, the background westward velocity is $1.4 \mathrm{~cm} \mathrm{~s}^{-1}$ and the mean total velocity is $7.6 \mathrm{~cm} \mathrm{~s}^{-1}$. This evaluation of the background velocity using float trajectories between $15^{\circ} \mathrm{W}$ and the $20^{\circ} \mathrm{W}$ is in good agreement with the 3 year mean velocity across the section (Figure 7) where we can observe a velocity between 1.0 and $2.0 \mathrm{~cm} \mathrm{~s}^{-1}$ in the core of the 

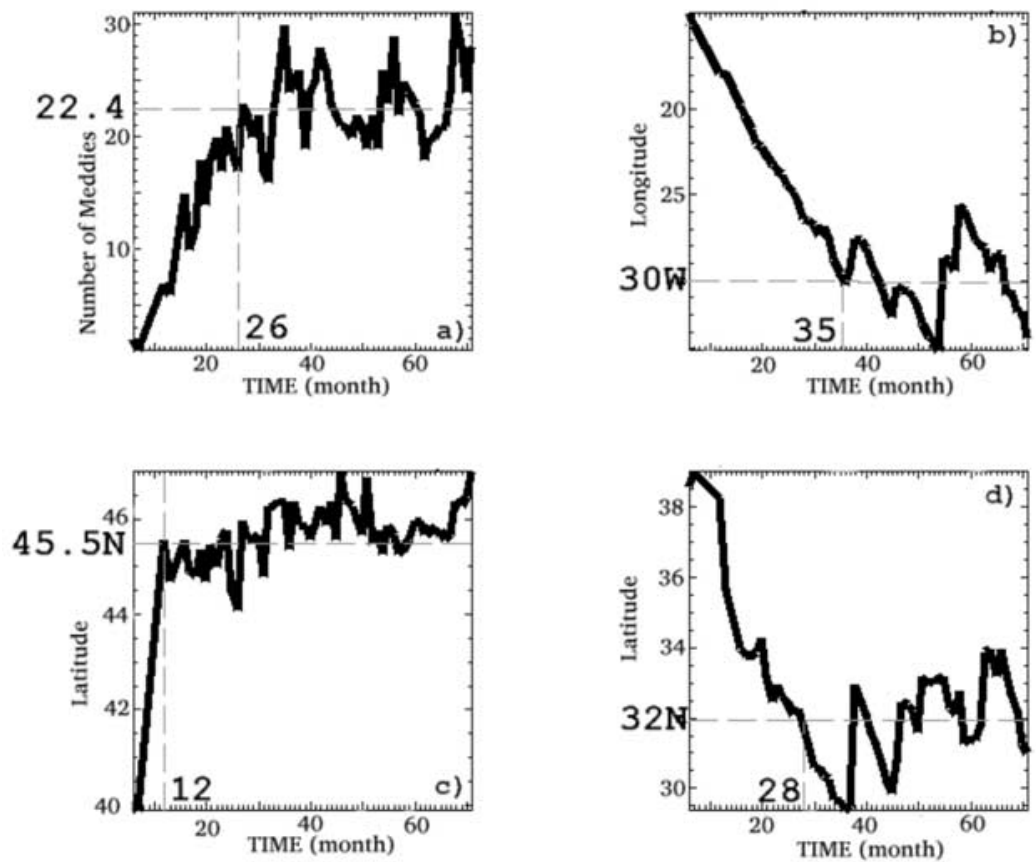

Figure 13. Temporal evolution during the 72 months of simulation of (a) the total number of meddies, (b) the longitude of the more westward meddies, (c) the latitude of the most northerly meddies, and (d) the latitude of the more southerly meddies.

branch 1 , between 1.0 and $3.0 \mathrm{~cm} \mathrm{~s}^{-1}$ in the core of the branch 2 and between 1.0 and $3.0 \mathrm{~cm} \mathrm{~s}^{-1}$ in the core of the branch 3 . Trajectories can be classified by their geographical area. (1) South of $35^{\circ} \mathrm{N}$. Only one float in this simulation is situated at this latitude and crosses the $15^{\circ} \mathrm{W}$ and the $20^{\circ} \mathrm{W}$ longitudes. The southern floats are principally advected in a southwest direction and many of them are trapped in the Horseshoe Seamounts area. (2) Between 35 and $40^{\circ} \mathrm{N}$. Most of the floats trapped in meddies and crossing the $15^{\circ} \mathrm{W}$ and the $20^{\circ} \mathrm{W}$ lines are in this area. They represent $37.8 \%$ of the selected floats, the background westward velocity is $1 \mathrm{~cm} . \mathrm{s}^{-1}$ and the mean total velocity is $8.6 \mathrm{~cm} \mathrm{~s}^{-1}$. (3) North of $40^{\circ} \mathrm{N}$. The floats trapped in meddies at this latitude represent $22.2 \%$ of the selected floats, the background westward velocity is $1.3 \mathrm{~cm} \mathrm{~s}^{-1}$ and the mean total velocity is $7.9 \mathrm{~cm} \mathrm{~s}^{-1}$. (4) The remaining floats, $37.8 \%$ of them, are not trapped in meddies. This percentage $(62.2 \%)$ cannot be viewed as a measurement of the exact proportion of the meddies inside the MW. Indeed, even if their initial positions are regularly distributed, our criteria selected floats preferentially trapped in energetic structures like eddies or strong currents. In this case, both velocities computed with float trajectories should represent the most intense MW current. The background westward velocity $\left(1.9 \mathrm{~cm} \mathrm{~s}^{-1}\right)$ is nevertheless in agreement with other estimations in the model or in the measurements (section 3.2). The mean total kinetic energy in the meddies is obviously greater than in the background flow.

\subsubsection{Angular Velocities of Meddies}

[52] The rotation periods in the measurements are very different depending on the observed meddy. Richardson and Tychensky [1998] and Bower et al. [1997] have esti- mated with Lagrangian float trajectories a mean period of 3 and 24 days, with a mean value of 8 days.

[53] Although the period in the model also exhibits a wide distribution (between 12 and 33 days) the mean value is larger (20 days). This underestimation of the angular velocity in the model is probably linked to the two other principal biases in the meddy representation, i.e., the overestimation of the size of the meddies and the underestimation of the temperature and salinity anomalies. In the observations, the smaller warmer and saltier meddies create larger gradients, intensifying the dynamical characteristics of the meddies.

\subsection{Meddies Splitting and Coalescence}

[54] Events of meddy splitting and meddies coalescences have been observed by Schultz Tokos et al. [1994] and Richardson et al. [2000]. An illustration of these events in the model is shown, Figure 14, on the salinity field at $870 \mathrm{~m}$. This figure displays one field every 20 days, starting 13 July 1998. At this date there is one coherent structure situated at $20.5^{\circ} \mathrm{W}, 39.8^{\circ} \mathrm{N}$, with a salinity maximum of 36.27 psu. During August 1998, this meddy is elongated and two salinity maxima are created. Their salinity is decreased by 0.06 psu compared to the single initial structure. In September and October, two different meddies of similar size and with the same salinity are clearly formed. Lastly, in November, these two structures coalesce into one meddy situated at $24^{\circ} \mathrm{W}$, $39^{\circ} \mathrm{N}$. The result of the 5 month life of this meddy is a displacement of $400 \mathrm{~km}$ and a salinity decrease of $0.16 \mathrm{psu}$. This displacement is further than the mean westward velocity estimated in section 4.3 .2 at $440 \mathrm{~km} / \mathrm{yr}$, and the decrease of salinity is very large compared to 


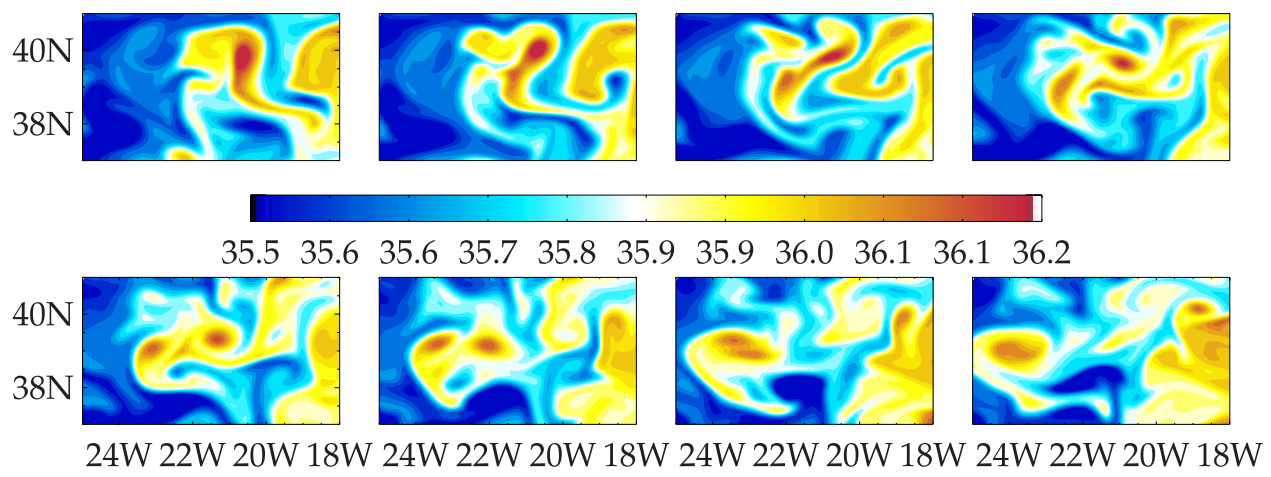

Figure 14. Salinity field (psu) at $870 \mathrm{~m}$ depth. Evolution of a meddy between 13 July and 30 November. There is one plot every 20 days. Note the separation of a meddy into two different structures and the coalescence of these two structures into one.

other meddies. With such a salinity decrease rate, the lifetime of a meddy would be 250 days instead of the usual period of several years found with noncoalescent meddies.

[55] Compared to the fastest mesoscale oceanic processes, only a few days are necessary to split/coalesce meddies. In this example (Figure 14), the two events occur on the same structure but in the model splitting is more often encountered than coalescence. Splitting is one of the causes of the dissipation of a meddy: either by the interaction with fresher and cooler currents, or by interaction with the bathymetry, particularly in the Horseshoe Seamounts in the south or in the Biscay seamount in the north.

\subsection{Meddy Classification}

\subsubsection{Steady States}

[56] The top right curve (Figure 13a) indicates the number of meddies selected with the third criterion described in section 4.1 during a 5 year simulation. Almost 2 years of simulation are necessary to stabilize the number of meddies (22 on average between April 1998 and August 2002) and reach what is called here a "steady state." The time needed to reach the most western (Figure 13b), the most northern (Figure 13c) or the most southern positions (Figure 13d) are very different.

[57] In the western direction, the meddies drift the furthest away from the formation area and 35 months are needed for a meddy to reach the $30^{\circ} \mathrm{W}$ longitude, which is the mean value of the most westward position at the steady state. The most western position of a meddy in the simulation is around $34^{\circ} \mathrm{W}$, i.e., $2600 \mathrm{~km}$ away. This occurs after 55 (and 70) months of simulation. The simulation is not long enough to make conclusions about cyclic phenomena. In the north direction, the mean value of the more northerly position during the steady state is $45.5^{\circ} \mathrm{N}$. In this direction, the excursion is only $7^{\circ}-10^{\circ}$, and the time needed to find a meddy at this latitude is 12 months, the more northerly position is $47^{\circ} \mathrm{N}$.

[58] The maximum displacement of $5^{\circ}$ in the south direction is due to a systematic interaction and the consecutive dissipation of the meddies with the seamounts. The time to reach the $32^{\circ} \mathrm{N}$ position (mean value of the more southerly position during the steady state) is 28 months, and the most southerly position is reached after 35 months of simulation. It seems that the model underestimates the most southerly position of the meddies. This is due to the position of the meddy formation, which is mainly at Tejo Plato rather than Cape St. Vincent in the simulation. Richardson and Tychensky [1998] have analyzed the meddies observed in the Canary basin during the SEMAPHORE experiment, tracking meddies up to $20^{\circ} \mathrm{N}$. Our meddy geographical "steady state" is defined when all the boundary limits of the box bounded by $30^{\circ} \mathrm{W}, 47^{\circ} \mathrm{N}$ and $32^{\circ} \mathrm{N}$ have been crossed by at least one meddy.

\subsubsection{Size Classification}

[59] The meddy counting method described in section 4.1 allows us to classify them by size. Using the criteria applied to the salinity field at $870 \mathrm{~m}$, we estimated the shape ellipsoid area including all the selected points. The ellipsoid is considered a good approximation of the geometric meddy boundaries. In this approximation, the axes of the ellipsoid are parallel to the grid of the model, with a precision of around $20 \mathrm{~km}$ (four grid points). The ellipsoids are mainly circular, and the chance of finding an axis three times larger than the minor one is very slim. To estimate the size of the meddies, the index is the size of the minor axis of the approximated ellipsoid. The mean number of meddies during the 4 years of simulation, between March 1998 and August 2002, is 22.4 with extrema values of 18 and 27 (Figure 15).

[60] We divide the meddy population into four size classes (class 1: $<25 \mathrm{~km}$; class 2: $<50 \mathrm{~km}$; class 3: $<75 \mathrm{~km}$; and class 4: $>75 \mathrm{~km}$ ). The class 2 and 3 populations have a similar mean of approximately 7 , with extrema ranging between 5 and 10 . They represent $65 \%$ of the total number of meddies. The smallest meddies (radius $<25 \mathrm{~km}$ ) represent $20 \%$ of the total number; the variability of the population of these small structures is large compared to the mean (between 1 and 9). This can be explained by the shrinking of the meddies during their lives. The largest meddies (radius $>75 \mathrm{~km}$ ) represent only $15 \%$ and their number is more stable than for the smallest meddies, varying between 2 and 4 .

\subsubsection{Area Classification}

[61] The counting method described in section 4.1 also allows us to classify the meddies by geographical domain during the number of meddy steady state. Four areas (NW, SW, NE, SE) are defined as north or south of $40^{\circ} \mathrm{N}$ and east 


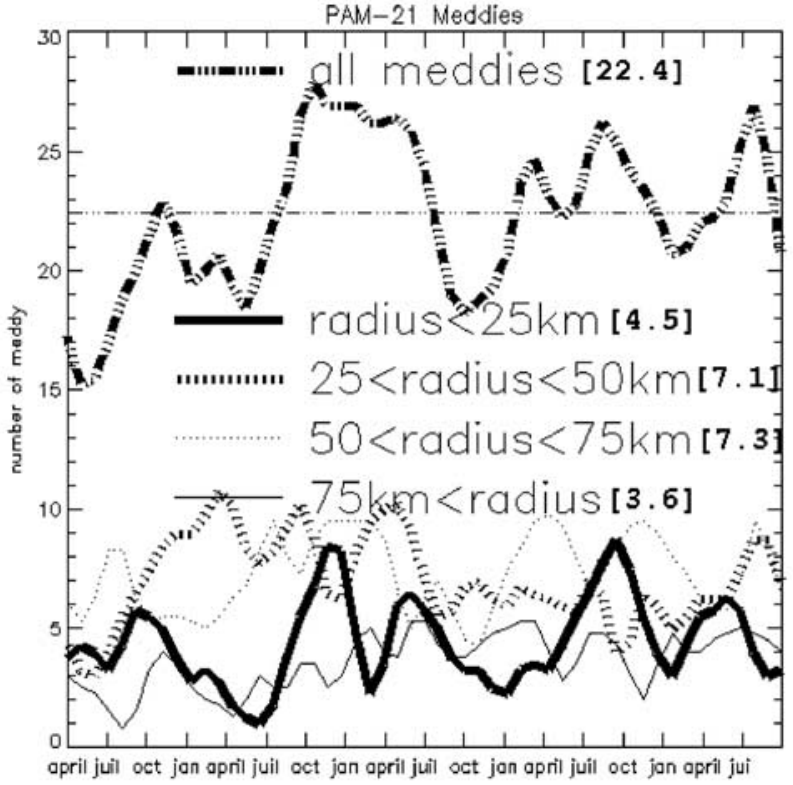

Figure 15. Temporal evolution of the number of meddies classified according to size. This time series begins in April 1998, when the number of meddies is stabilized in the model. The mean values for each class are displayed between brackets.

or west of $18^{\circ} \mathrm{W}$. The choice of these areas is justified by geographical and topographic criteria. The $40^{\circ} \mathrm{N}$ latitude separates the southern and middle branches (Cape St. Vincent and Tejo Plato) from the northern ones (Cape Finisterre) defined in section 3.2. East of $18^{\circ} \mathrm{W}$ longitude is the seamount area (Horseshoe Seamounts in the south and Biscay Seamount in the north) where the meddies often interact with the bathymetry. Over the 4 year simulation there are respectively $3,7.5,7.1$ and 4.8 meddies in the areas. That means $54.9 \%$ in the southern part of the domain and $53.1 \%$ in the eastern part (Table 2). We will see in section 6 that these values are quite different with the noslip lateral friction condition.

\subsection{Meddy Contribution to Salinity Transport}

[62] The main topic of this study is the representation of the meddies with this high-resolution model. However, it also proves very interesting to evaluate the impact of the meddies on the large-scale circulation. This 5 year simulation is not long enough to evaluate the impact of the MW and the meddies over the thermohaline circulation, but it is interesting to quantify the contribution of the meddies to the salt anomaly transport in the North Atlantic. An estimation of the salinity transport has been made by Arhan et al. [1994]. The hydrographic section, called "Bord-Est section," follows the east Atlantic coast between $20^{\circ} \mathrm{W}, 20^{\circ} \mathrm{N}$ and $10^{\circ} \mathrm{W}, 60^{\circ} \mathrm{N}$. During the cruise, three meddies were observed, and Arhan et al. [1994] estimated that the meddy contribution to the anomaly salinity transport across this section was $55 \%$. In the model, we have estimated the meddy contribution to the anomaly salinity transport through a slightly different "Bord-Est section." Our section crosses the entire model domain from $8^{\circ} \mathrm{W}, 57^{\circ} \mathrm{N}$ to $30^{\circ} \mathrm{W}$, $9^{\circ} \mathrm{N}$. The salinity and the normal velocity are calculated at each point of the model along this section.

[63] The salinity anomaly is calculated for each model level as described in section 4.1. This computation is performed every month using a 5 day mean model output. The anomaly salinity transport is between 2.8 and $5.8 \mathrm{~Sv}$ psu for the total MW. The large variability in the meddy formation and in the MW vein explains the large variability of the contribution of the meddies to the salinity anomaly transport. The salinity anomaly transport in the smallest meddies is around $0.15 \mathrm{~Sv}$ psu and in the largest it reaches $2.5 \mathrm{~Sv}$ psu. The percentage of the meddy contribution can vary between 0 to $100 \%$ with time the mean value being $51 \%$ during the period.

\section{Summary and Discussion}

[64] This study uses a model with a high-horizontalresolution model $(3.5-7 \mathrm{~km})$ based on the OPA ocean general circulation model. In this configuration, the MW outflow is quite well simulated with a maximum of salinity situated at a depth of around $1000 \mathrm{~m}$, and the separation of the MW tongue into four branches in the Atlantic Ocean.

[65] The maximum of temperature and salinity in the meddies are respectively between $11.4^{\circ}$ and $12.0^{\circ} \mathrm{C}$, and between 36.0 and 36.2 psu. The observed meddies are generally saltier $(+0.1-0.2 \mathrm{psu})$ and warmer $\left(+0.5^{\circ}-\right.$ $\left.1.0^{\circ} \mathrm{C}\right)$ than the simulated ones, apart from the northern meddy where the thermohaline characteristics are in good agreement with the observations. This fresh and cold bias in the model is due to the relaxation of the MW outflows toward a fresher and colder climatological data set.

[66] The radii of the simulated meddies are mostly found between 25 and $75 \mathrm{~km}$, which is the most commonly observed size for these structures. Nevertheless, a nonnegligible number of simulated meddies $(15 \%)$ have a radius greater than $75 \mathrm{~km}$, which is larger than the largest meddies ever observed.

[67] The advection velocity of the modeled meddies, around $1.4 \mathrm{~cm} \mathrm{~s}^{-1}$, is also a commonly accepted value, but their period of rotation, estimated around 20 days, is comparable to the largest observed values. The realistic lifetime of the structures we track for several years shows that the diffusivity processes in the model are well adapted. The mean number of meddies (22 in the PAM21 simulation) is also in good agreement with the observations. We plan in the near future to use an objective analysis method [Hodges, 1994] to identify and track the meddies in a more systematic way over a longer period.

[68] The realism of the meddies compared to observations allows us to conclude that the PAM model is an efficient tool to simulate: the number of meddies; their geographical

Table 2. Geographical Distribution of the Meddies in the Four Areas (NW, NE, SW, SE) Separated by the $18^{\circ} \mathrm{W}$ Longitude and the $40^{\circ} \mathrm{N}$ Latitude $^{\mathrm{a}}$

\begin{tabular}{lccc}
\hline & West, \% & East, \% & Total, \% \\
\hline North, \% & 13.4 & 31.7 & 45.1 \\
South, \% & 33.5 & 21.4 & 54.9 \\
Total, \% & 46.9 & 53.1 & 100 \\
\hline
\end{tabular}

${ }^{a}$ These percentages are computed during the simulation period between April 1998 and August 2002. 
distribution; their trajectories; their interaction with the bathymetry; the frequency and the area of formation. These phenomena are difficult to measure, track and sample. We also know that several improvements to the model are possible. For example, the main position of the meddies birthplace which can be relocated at Cape St. Vincent by changing the lateral boundary friction in no-slip condition instead of the free slip used in this simulation.

[69] A good representation of the meddies in a global ocean basin model is an original result in the ocean modeling community. This study shows the good potential of the PAM model for simulating mesoscale structures in the North Atlantic Ocean and Mediterranean Sea. In the Mercator forecasting system, the PAM model is already implemented and can be used to forecast trajectories and thermohaline characteristics of the meddies. During the last decade, many studies concerned altimetry observation of surface mesoscale structures. Although first attempts to observe meddies from space with altimetry satellites have been recently made [Yan et al., 2004], the PAM model in the Mercator system has been able to simulate meddies and track them in real time.

[70] Acknowledgments. This paper is dedicated to Christian Le Provost, who has managed the development and the validation of the North Atlantic and Mediterranean Sea Prototype at Mercator Océan. The authors sincerely thank the Clipper Project team for their help and their advice. Thank you to Gilles Garric for rereading and correcting the first version of the manuscript and to the reviewers for their useful comments and suggestions.

\section{References}

Aiki, H., and T. Yamagata (2004), A numerical study on the successive formation of meddy-like lenses, J. Geophys. Res., 109, C06020, doi:10.1029/2003JC001952.

Arhan, M., A. Colin de Verdière, and L. Mémery (1994), The eastern boundary of the subtropical North Atlantic, J. Phys. Oceanogr., 24, 1295- 1316

Armi, L., and W. Zenk (1984), Large lenses of highly saline Mediterranean Water, J. Phys. Oceanogr., 14, 1560-1576.

Beckmann, A., and R. H. Käse (1989), Numerical simulation of the movement of a Mediterranean water lens, Geophys. Res. Lett., 16, $65-68$.

Bower, A. S., L. Armi, and I. Ambar (1997), Lagrangian observation of meddy formation during A Mediterranean Undercurreznt Seeding experiment, J. Phys. Oceanogr., 27, 2545-2575.

Bower, A. S., N. Serra, and I. Ambar (2002), Structure of the Mediterranean Undercurrent and Mediterranean Water spreading around the southwestern Iberian Peninsula, J. Geophys. Res., 107(C10), 3161, doi:10.1029/ 2001JC001007.

Colin de Verdière, A. (1992), On the southward motion of the Mediterranean salt lenses, J. Phys. Oceanogr., 22, 413-420.

Dewar, W. K. (2002), Baroclinic eddy interaction with isolated topography, J. Phys. Oceanogr., 32, 2789-2805.

Drillet, Y., R. Bourdalle-Badie, and L. Siefridt (2002), Test de sensibilité dans le modèle haute résolution Mercator, Ann. Math. Blaise Pascal, 9, $283-298$.

Hodges, K. I. (1994), A general method for tracking analysis and its application to meteorological data, Mon. Weather Rev., 122, 2573-2586.

Hopkins, T. S. (1999), Thermohaline forcing of the Gibraltar exchange, J. Mar. Syst., 20, 1-31.

Iorga, M. C., and M. S. Lozier (1999a), Signatures of the Mediterranean outflow from a North Atlantic climatology: 1. Salinity and density fields, J. Geophys. Res., 104, 25,985-26,009.

Iorga, M. C., and M. S. Lozier (1999b), Signatures of the Mediterranean outflow from a North Atlantic climatology: 2. Diagnostic velocity fields, J. Geophys. Res., 104, 26,011-26,029.

Johnson, G. C., T. B. Sanford, and M. O. Baringer (1994), Stress of the Mediterranean outflow plume: Part I. Velocity and water property measurement, J. Phys. Oceanogr., 24, 2072-2083.
Jungclaus, J. H. (1999), A three-dimensional simulation of the formation of anticyclonic lenses (meddies) by the instability of an intermediate depth boundary current, J. Phys. Oceanogr., 29, 1579-1598.

Killworth, P. D. (1986), On the propagation of isolated multilayer and continuously stratified eddies, J. Phys. Oceanogr., 16, 709-716.

Madec, G., P. Delecluse, M. Imbard, and C. Lévy (1998), OPA8.1: Ocean general circulation model reference manual, report, 97 pp., Inst. Pierre Simon Laplace, Paris.

McDowell, S. E., and T. Rossby (1978), Mediterranean Water: An intense mesoscale eddy off the Bahamas, Science, 202, 1085-1087.

Mediterranean Data Archaeology and Rescue (2002), Cruise inventory, observed and analysed data of temperature and bio-chemical parameters, in MEDAR/MEDATLAS 2002 Database [CD-ROM], Fr. Res. Inst. for Exploit. of the Sea, Issy-les-Moulineaux.

Morel, Y. (1995), The influence of an upper thermocline current on intrathermocline eddies, J. Phys. Oceanogr., 12, 3247-3252.

Morel, Y., and J. C. McWilliams (1997), Evolution of isolated interior vortices in the ocean, J. Phys. Oceanogr., 27, 727-748.

Paillet, J., B. Le Cann, X. Carton, Y. Morel, and A. Serpette (2002), Dynamics and evolution of northern meddy, J. Phys. Oceanogr., 32, $55-79$.

Pichevin, T., and D. Nof (1996), The eddy canon, Deep Sea Res., Part I, 43, $1475-1507$.

Pingree, R. D., and B. Le Cann (1993), A shallow meddy (a smeddy) from the secondary Mediterranean salinity maximum, J. Geophys. Res., 98, 20,169-20,185.

Reynaud, T., P. Le Grand, H. Mercier, and B. Barnier (1998), A new analysis of hydrographic data in the Atlantic and its application to an inverse modeling study, Int. World Ocean Circ. Exper. Newsl., 32, 2931.

Richardson, P. L., and A. Tychensky (1998), Meddy trajectories in the Canary Basin measured during the SEMAPHORE experiment, 19931995, J. Geophys. Res., 103, 25,029-25,045.

Richardson, P. L., M. S. McCartney, and C. Maillard (1991), A search for meddies in historical data, Dyn. Atmos. Oceans, 15, 241-265.

Richardson, P. L., A. S. Bower, and W. Zenk (2000), A census of meddies tracked by floats, Prog. Oceanogr., 45, 209-250.

Schultz Tokos, K. L., H. H. Hinrichsen, and W. Zenk (1994), Merging and migration of two meddies, J. Phys. Oceanogr., 24, 21292141 .

Siefridt, L., Y. Drillet, R. Bourdallé-Badie, K. Béranger, C. Talandier, and E. Greiner (2002), Mise en oeuvre du modèle Mercator à haute résolution sur l'Atlantique nord et la Méditerranée, Newsl. Mercator, 5, $1-10$.

Smith, R. D., M. E. Maltrud, F. O. Bryan, and M. W. Hecht (2000), Numerical simulation of the North Atlantic Ocean at $1 / 10^{\circ}$, J. Phys. Oceanogr., 30, 1532-1561.

Smith, W. H. F., and D. T. Sandwell (1994), Bathymetric prediction from dense satellite altimetry and sparse shipboard bathymetry, J. Geophys. Res., 99, 21,803-21,824.

Sparrow, M., O. Boebel, V. Zevakis, W. Zenk, A. Cantos-Figuerola, and W. Jon Gould (2002), Two circulation regimes of the Mediterranean outflow revealed by Lagrangian measurements, J. Phys. Oceanogr., 32, $1322-1330$.

Talandier, C., S. Theetten, and F. Gaillard (2001), Validation de PAM-05 en Atlantique Nord-Est., report, Fr. Res. Inst. for Exploit. of the Sea, Issy-les-Moulineaux.

Treguier, A.-M., et al. (2001), An eddy-permitting model of the Atlantic circulation: Evaluating open boundary conditions, J. Geophys. Res., 106, 22,115-22,129.

Tychensky, A., and X. Carton (1998), Hydrological and dynamical characterization of meddies in the Azores region: A paradigm for baroclinic vortex dynamics, J. Geophys. Res., 103, 25,061-25,079.

Yan, X.-H., Y.-H. Jo, W. T. Liu, and M.-X. He (2004), Can we observe and study the Mediterranean outflow and meddies from satellite remote sensing?, Proc. SPIE, 5233, 158-168.

Zenk, W., K. Shultz Tokos, and O. Boebel (1992), New observations of meddy movement south of Tejo plateau, Geophys. Res. Lett., 19, 23892392 .

R. Bourdallé-Badie, Y. Drillet, C. Le Provost, and L. Siefridt, GIP Mercator Océan, $8 \backslash 10$ parc Technologique du Canal, F-31520 Ramonville St. Agne, France. (rbourdal@mercator-ocean.fr; yann.drillet@mercatorocean.fr; cleprovost@mercator-ocean.fr; siefridt@cerfacs.fr) 